\title{
Impacts of stratospheric sulfate geoengineering on tropospheric ozone
}

\author{
Lili Xia ${ }^{1}$, Peer J. Nowack ${ }^{2, a}$, Simone Tilmes ${ }^{3}$, and Alan Robock ${ }^{1}$ \\ ${ }^{1}$ Department of Environmental Sciences, Rutgers University, New Brunswick, New Jersey, USA \\ ${ }^{2}$ Department of Chemistry, Centre for Atmospheric Science, University of Cambridge, Cambridge, UK \\ ${ }^{3}$ Atmospheric Chemistry Observations and Modeling Laboratory, National Center for Atmospheric Research, Boulder, \\ Colorado, USA \\ ${ }^{a}$ now at: Grantham Institute and Department of Physics, Faculty of Natural Sciences, Imperial College London, London, UK
}

Correspondence to: Lili Xia (lxia@envsci.rutgers.edu)

Received: 8 May 2017 - Discussion started: 19 May 2017

Revised: 22 August 2017 - Accepted: 25 August 2017 - Published: 9 October 2017

\begin{abstract}
A range of solar radiation management (SRM) techniques has been proposed to counter anthropogenic climate change. Here, we examine the potential effects of stratospheric sulfate aerosols and solar insolation reduction on tropospheric ozone and ozone at Earth's surface. Ozone is a key air pollutant, which can produce respiratory diseases and crop damage. Using a version of the Community Earth System Model from the National Center for Atmospheric Research that includes comprehensive tropospheric and stratospheric chemistry, we model both stratospheric sulfur injection and solar irradiance reduction schemes, with the aim of achieving equal levels of surface cooling relative to the Representative Concentration Pathway 6.0 scenario. This allows us to compare the impacts of sulfate aerosols and solar dimming on atmospheric ozone concentrations. Despite nearly identical global mean surface temperatures for the two SRM approaches, solar insolation reduction increases global average surface ozone concentrations, while sulfate injection decreases it. A fundamental difference between the two geoengineering schemes is the importance of heterogeneous reactions in the photochemical ozone balance with larger stratospheric sulfate abundance, resulting in increased ozone depletion in mid- and high latitudes. This reduces the net transport of stratospheric ozone into the troposphere and thus is a key driver of the overall decrease in surface ozone. At the same time, the change in stratospheric ozone alters the tropospheric photochemical environment due to enhanced ultraviolet radiation. A shared factor among both SRM scenarios is decreased chemical ozone loss due to reduced tropo-
\end{abstract}

spheric humidity. Under insolation reduction, this is the dominant factor giving rise to the global surface ozone increase. Regionally, both surface ozone increases and decreases are found for both scenarios; that is, SRM would affect regions of the world differently in terms of air pollution. In conclusion, surface ozone and tropospheric chemistry would likely be affected by SRM, but the overall effect is strongly dependent on the SRM scheme. Due to the health and economic impacts of surface ozone, all these impacts should be taken into account in evaluations of possible consequences of SRM.

\section{Introduction}

\subsection{Atmospheric ozone}

It is well known that sulfate aerosols in the stratosphere enhance heterogeneous chemical reactions that lead to enhanced ozone depletion after larger volcanic eruptions (Solomon, 1999). With present-day anthropogenic halogen loading, the aerosols provide additional surface area for heterogeneous reactions that activate halogens and hence increase catalytic ozone destruction, especially in high latitudes (Tie and Brasseur, 1995). This has been modeled and observed following the large $1982 \mathrm{El}$ Chichón and 1991 Pinatubo volcanic eruptions (Tie and Brasseur, 1995; Portman et al., 1996).

However, volcanic eruptions do not only affect stratospheric ozone but also impact tropospheric composition, of- 
ten due to stratosphere-troposphere coupled effects. The 1991 Pinatubo eruption, for example, has been linked to changes in the stratosphere-troposphere exchange (STE) of ozone (Aquila et al., 2012, 2013; Pitari et al., 2016). In addition, the stratospheric ozone decrease led to an invigorated photochemical environment in the troposphere due to enhanced downward chemically active ultraviolet (UV) radiation (Tang et al., 2013).

This study focuses on tropospheric ozone, in particular surface ozone concentration changes. Surface ozone is of central importance to Earth's environment, and as an air pollutant it adversely impacts human health (e.g., Kampa and Castanas, 2008) and the ecosystem (e.g., Mauzeral and Wang, 2001; Ashmore, 2005; Ainsworth et al., 2012). There have been numerous studies of the observed surface ozone trend (e.g., Cooper et al., 2014), identifying ozone sources and sinks (e.g., Wild, 2007), predicting future changes (e.g., Young et al., 2013), and understanding the impacts of such changes (e.g., Silva et al., 2013). Global surface ozone concentrations are estimated to have doubled since the preindustrial period (Vingarzan, 2004), mainly due to increased emissions of ozone precursors associated with industrialization (e.g., Forster et al., 2007). Differences in future tropospheric ozone concentrations will be strongly dependent on the emission pathway followed (Stevenson et al., 2006), which will determine both in situ tropospheric chemical production of ozone and transport from the ozone-rich stratosphere (Collins et al., 2003; Wild et al., 2012; Neu et al., 2014).

\subsection{Differences between sulfate and solar geoengineering}

The progression of global warming, slow mitigation efforts, and our relatively limited adaptive capacity force consideration of solar radiation management (SRM) geoengineering as one possible strategy to avoid many of the most undesirable consequences of global warming (Crutzen, 2006; Wigley, 2006; Tilmes et al., 2016a). The above discussed factors controlling tropospheric ozone concentrations could be affected by SRM schemes (Nowack et al., 2016). Here we compare a proposed geoengineering scheme, stratospheric sulfur injection, to solar irradiance reduction. Both schemes would cool Earth's surface by reducing sunlight reaching the surface, either by aerosols reflecting sunlight or by artificially reducing the solar constant in a climate model, but sulfate geoengineering would strongly heat the stratosphere and provide aerosol surfaces for chemical reactions. Previous studies have shown that injected sulfur chemically forms sulfate aerosols within a couple of weeks. The aerosol layer absorbs near infrared solar radiation as well as outgoing longwave radiation and results in stratospheric warming (e.g., Tilmes et al., 2009; Ammann et al., 2010; Jones et al., 2011). Additionally, changes in ozone and advection impact the warming in the stratosphere (Richter et al., 2017). Under solar reduction, the stratosphere would be cooler due to reduced shortwave heating (Govindasamy and Caldeira, 2000), although simultaneous stratospheric ozone changes (if considered) may buffer this effect (Nowack et al., 2016).

One of the most important differences between the two scenarios is that if a permanently enhanced stratospheric aerosol layer is artificially created in an attempt to reduce anthropogenic global warming, the resulting strong ozone depletion, in particular in mid- and high latitudes, would have serious impacts on the biosphere, similar to the effects observed after large volcanic eruptions described above (Crutzen, 2006; Rasch et al., 2008a, b; Tilmes et al., 2008, 2009, 2012). This effect would have to be expected as long as there is anthropogenic halogen in the stratosphere. In the remote future, the decreasing burden of anthropogenic halogen will eventually result in the recovery of the ozone layer. Under such conditions additional stratospheric aerosols could actually have the opposite effect by deactivating ozonedepleting nitrogen oxides, thus leading to an increase in ozone in the stratosphere (Tie and Brasseur, 1995; Pitari et al., 2014). Overall, such changes to the stratosphere would also have important implications for tropospheric composition. Decreasing stratospheric ozone leads to more UV propagating through, with increasing ozone having the opposite effect, which would thus alter the photochemical environment of the troposphere in different ways (Tilmes et al., 2012; Nowack et al., 2016).

In the following sections, we describe the experimental set-up of the two geoengineering schemes and discuss some general climate impacts, followed by a detailed discussion of tropospheric and surface ozone changes. We also show that sulfate and solar geoengineering would impact the stratosphere differently, which implies further key differences in their potential influences on tropospheric composition. In this study, we examine the impacts of stratospheric sulfate geoengineering on tropospheric ozone for the first time.

\section{Model and experiment design}

We simulated both types of SRM schemes using the full tropospheric and stratospheric chemistry version of the Community Earth System Model-Community Atmospheric Model 4 (CESM CAM4-chem) with a horizontal resolution of $0.9^{\circ} \times 1.25^{\circ}$ (lat $\times$ long) and 26 levels from the surface to about $40 \mathrm{~km}(3.5 \mathrm{mb})$. The model has been shown to give a good representation of present-day atmospheric composition in the troposphere (Tilmes et al., 2016b) and stratosphere at $2^{\circ}$ resolution (Fernandez et al., 2017). Similar to the $2^{\circ}$ model version, the $1^{\circ}$ horizontal resolution version of the model also produces reasonable stratosphere and troposphere ozone chemistry (Figs. S1-S2 in the Supplement). CAM4chem is fully coupled to the Community Land Model version 4.0 with prescribed satellite phenology (CLM4SP), the Parallel Ocean Program version 2 (POP2) ocean model, and 

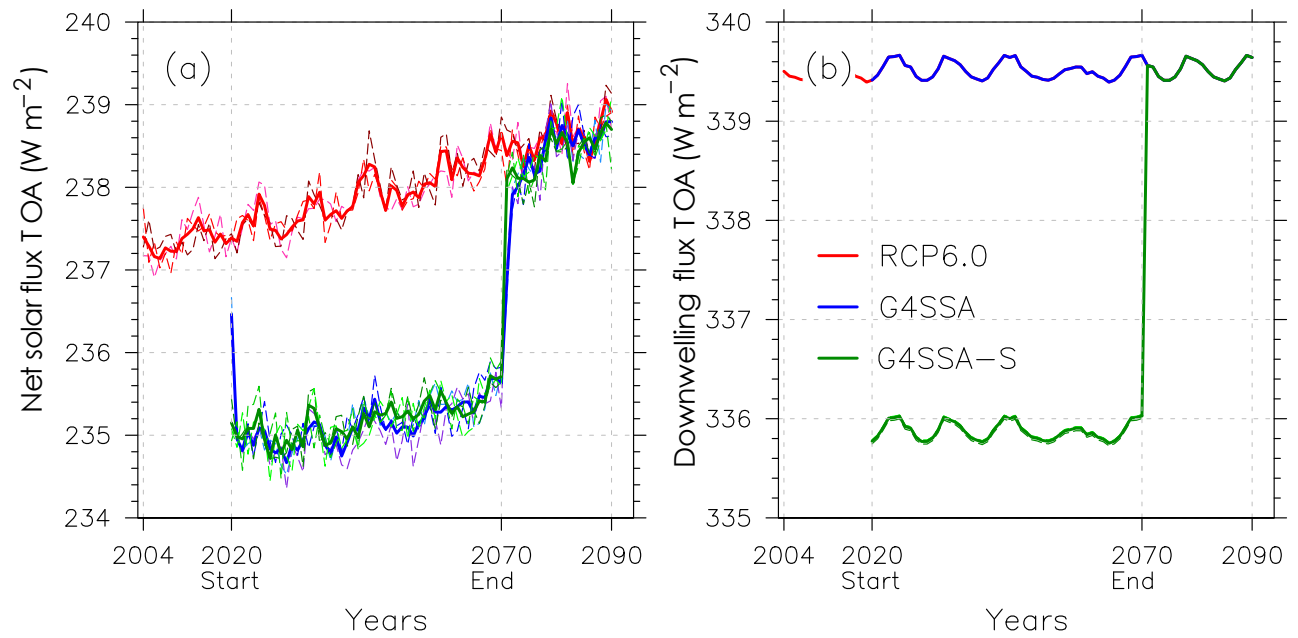

Figure 1. (a) Global averaged annual net solar flux at the top of the atmosphere $\left(\mathrm{W} \mathrm{m}^{-2}\right)$ and (b) downwelling solar flux at the top of the atmosphere $\left(\mathrm{W} \mathrm{m}^{-2}\right)$. Dashed lines are ensemble members, and solid lines are the average of three ensemble members. Geoengineering starts on 1 January 2020 and ends on 1 January 2070. The 11-year periodicity is imposed as a prediction of the sunspot cycle. In (b) the G4SSA curve exactly covers the RCP6.0 curve.

the Los Alamos sea ice model (CICE version 4). The tropospheric chemical mechanism in CAM4-chem is based on the Model for Ozone and Related chemical Tracers (MOZART) version 4 (Emmons et al., 2010). The stratospheric chemical mechanism is described in Kinnison et al. (2007), Lamarque et al. (2012), and Tilmes et al. (2015), and the complete chemical reactions included (photolysis, gas-phase chemistry, and heterogeneous chemistry) are listed in Tilmes et al. (2016b, Table A2). Reaction rates are updated following Jet Propulsion Laboratory 2010 recommendations (Sander et al., 2011). The model uses a nudged quasi-biennial oscillation (QBO), which means the QBO will not be modified by the radiative interaction of the aerosols. Interaction between aerosol burden and photolysis rates is not included in the model. Changes in photolysis rates in the troposphere depend on the stratospheric ozone column change (Kinnison et al., 2007). Increased ozone depletion as the result of geoengineering would therefore lead to an increase in UV in mid- and high latitudes. Since our model does not include the aerosol scattering effect on UV, expected UV reductions from the increased sulfate aerosol layer are not taken into account, which might result in an overestimation of the tropospheric photolysis. Volatile organic compound (VOC) emissions are simulated by the Model of Emission of Gases and Aerosols from Nature (MEGAN v2.1) (Guenther et al., 2012). The dynamical ocean model does not include any biogeochemical feedbacks and only the atmospheric and land models are coupled to the atmospheric chemistry component. The model configuration used here, but at $2^{\circ}$ resolution, is participating in the current phase of the Chemistry-Climate Model Initiative (Tilmes et al., 2016b; Morgenstern et al., 2017).

We compare three ensemble members each of the two geoengineering scenarios to a three-ensemble reference run with
Representative Concentration Pathway 6.0 (RCP6.0; Meinshausen et al., 2011) anthropogenic forcing from 2020 to 2089. Both geoengineering scenarios include RCP6.0 forcings. Our sulfate aerosol implementation is the G4 Specified Stratospheric Aerosol (G4SSA) experiment (Tilmes et al., 2015), whereas solar reduction geoengineering is the solar analog (hereafter G4SSA-S) by imposing a solar irradiance reduction with the same negative radiative forcing at the top of the atmosphere (TOA) as in G4SSA. G4SSA uses a prescribed stratospheric aerosol surface area distribution to mimic the effects of continuous emission into the tropical stratosphere at $60 \mathrm{mb}$ of $8 \mathrm{Tg} \mathrm{SO}_{2} \mathrm{yr}^{-1}$ from 2020 to 2069 . More details of this prescribed stratospheric aerosol distribution are given in Tilmes et al. (2015) and Xia et al. (2016). The G4SSA scenario then continues from 2070 to 2089 without imposed aerosols to study the termination effect of geoengineering. During the sulfate injection period, the net solar flux at the TOA was decreased by $2.5 \mathrm{~W} \mathrm{~m}^{-2}$ compared to RCP6.0 (Fig. 1a). This number was obtained by a double radiation call in the model in calculating the direct forcing of the prescribed aerosol layer. To attain the same TOA solar flux reduction in G4SSA-S, we reduced the total solar insolation by $14.7 \mathrm{~W} \mathrm{~m}^{-2}$ during $2020-2069$ assuming a global average planetary albedo of $0.32\left(14.7 \mathrm{~W} \mathrm{~m}^{-2}=\frac{2.5 \mathrm{~W} \mathrm{~m}^{-2} \times 4}{1.0-0.32}\right)$ (Fig. 1b). From 2070 on, we accordingly reset the total solar insolation back to the reference level to simulate the abrupt termination of geoengineering. 

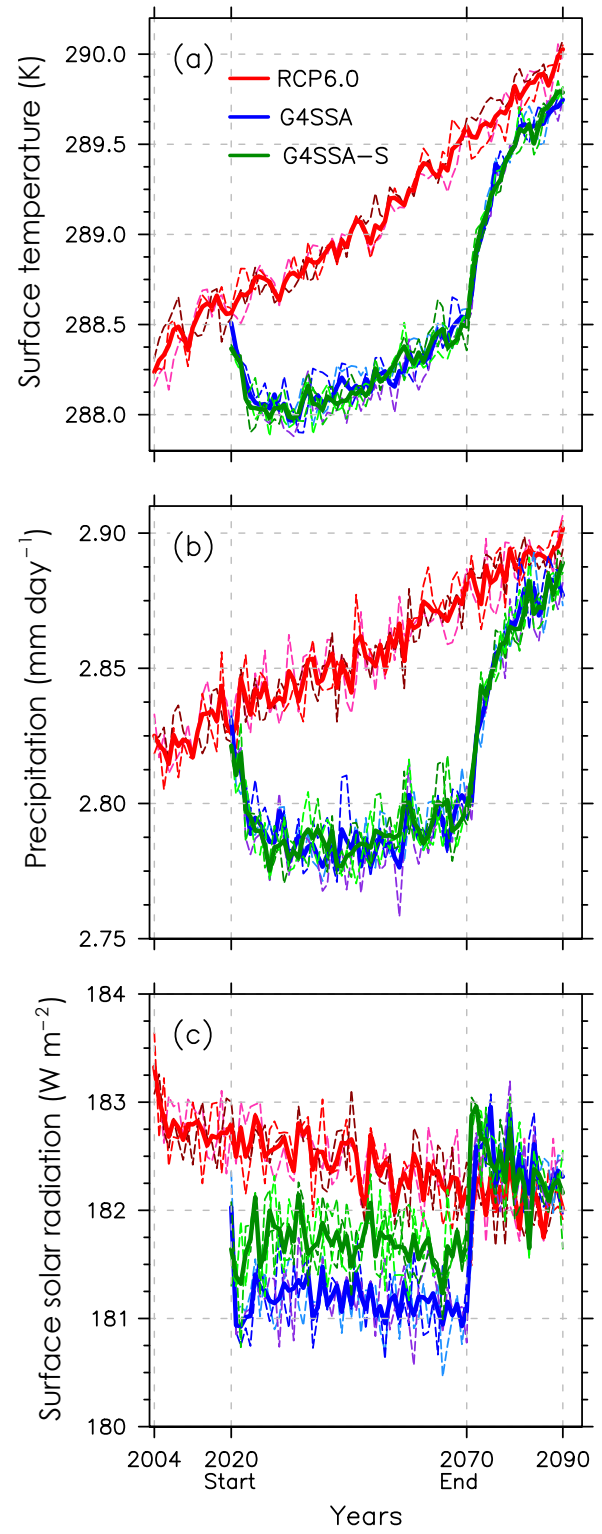

Figure 2. (a) Global averaged annual surface air temperature (K), (b) global averaged annual precipitation $\left(\mathrm{mm} \mathrm{day}^{-1}\right)$, and (c) downwelling surface solar radiation $\left(\mathrm{W} \mathrm{m}^{-2}\right)$. Dashed lines are ensemble members, and solid lines are the average of the three ensemble members. Geoengineering starts on 1 January 2020 and ends on 1 January 2070.

\section{Results and discussion}

\subsection{Climatology in G4SSA and G4SSA-S}

As a consequence of the same net all-sky TOA solar flux reduction in G4SSA and G4SSA-S (Fig. 1a), the two scenarios show approximately the same global mean surface temperature reduction of $0.8 \mathrm{~K}$ compared with RCP6.0 (Fig. 2a) (all values below are the average of the years 2030-2069, the last 40 years of geoengineering). After the termination of (a) G4SSA minus RCP6.0

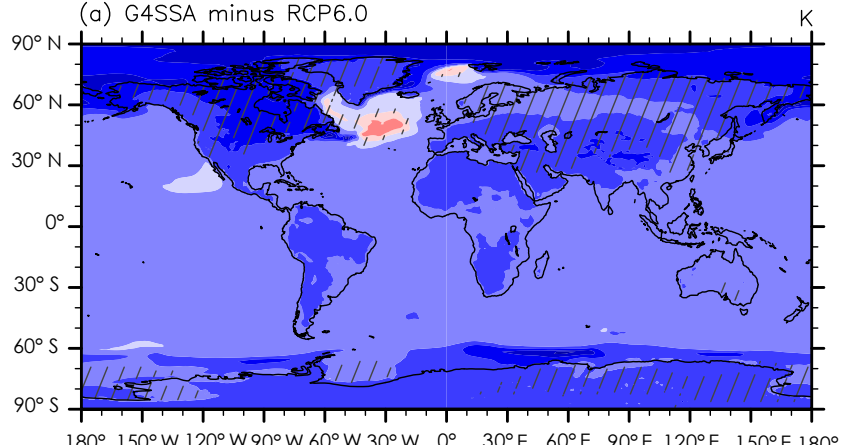

(b) G4SSA-S minus RCP6.0

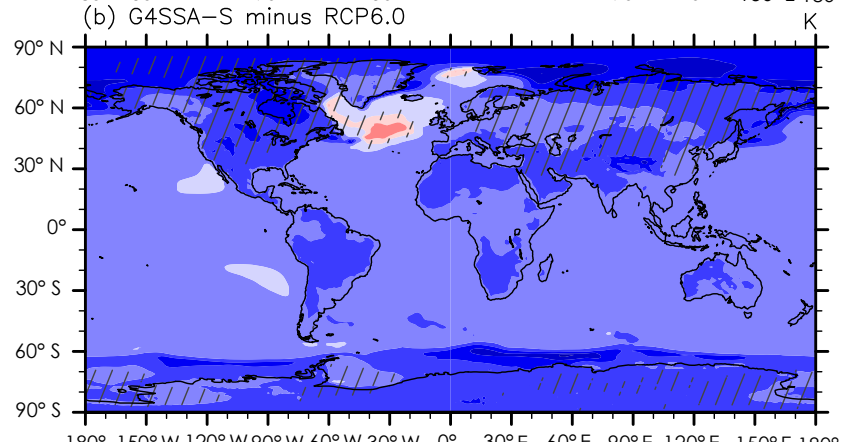

$180^{\circ} 150^{\circ} \mathrm{W} 120^{\circ} \mathrm{W} 90^{\circ} \mathrm{W} 60^{\circ} \mathrm{W} 30^{\circ} \mathrm{W} \quad 0^{\circ} \quad 30^{\circ} \mathrm{E} \quad 60^{\circ} \mathrm{E} \quad 90^{\circ} \mathrm{E} \quad 120^{\circ} \mathrm{E} \quad 150^{\circ} \mathrm{E} 180^{\circ}$

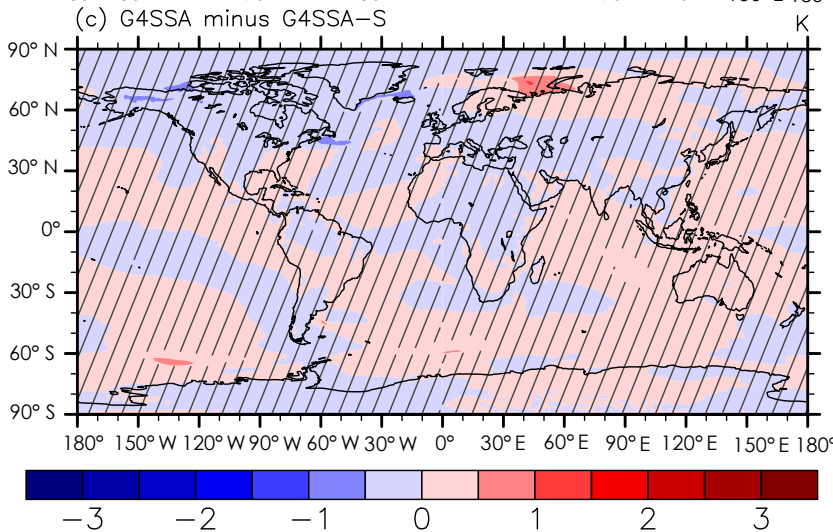

Figure 3. Global maps of surface temperature differences $(\mathrm{K})$ between (a) G4SSA and RCP6.0, (b) G4SSA-S and RCP6.0, and (c) G4SSA and G4SSA-S over the period 2030-2069. Hatched regions are areas with $p>0.05$ (where changes are not statistically significant based on a paired $t$ test).

geoengineering on 1 January 2070, the global mean surface temperature rapidly increases. Figure 3 shows the surface temperature differences between G4SSA, G4SSA-S, and RCP6.0 in the years 2030-2069. Consistent with the global average temperature change, the two geoengineering scenarios have similar temperature reduction patterns (Fig. 3a and b), and the differences between them are not significant in most regions (Fig. 3c). The similar warming in the North Atlantic under G4SSA and G4SSA-S relative to RCP6.0 (Fig. 3a and b) is due to the regional cooling under RCP6.0 as a result of slowing down of the Gulf Stream (Hartmann et al., 2013). The temperature difference between G4SSA and 


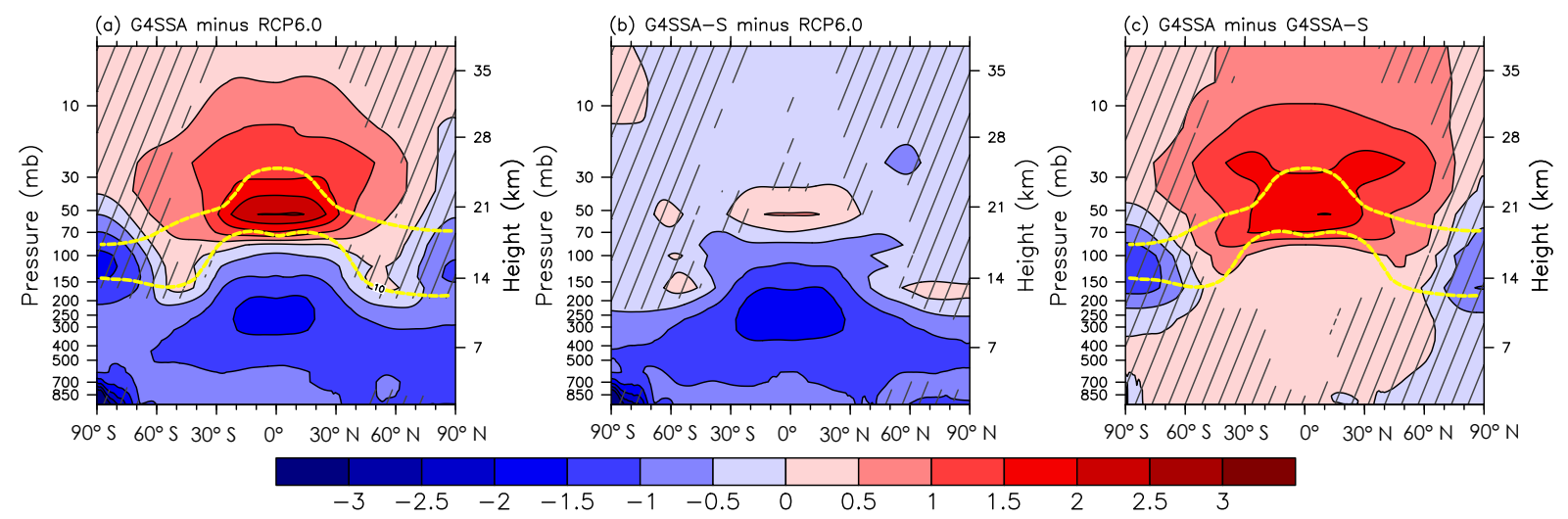

Figure 4. Zonal mean temperature differences $(\mathrm{K})$ in the geoengineering experiments (a) G4SSA minus RCP6.0, (b) G4SSA-S minus RCP6.0, and (c) G4SSA minus G4SSA-S. These are averaged for the three ensemble members for the years 2030-2069. Hatched regions are insignificant, with $p>0.05$. The yellow dashed lines in (a) and (c) are upper and lower limits of the prescribed sulfate aerosol (surface area density: $10 \mu \mathrm{m}^{2} \mathrm{~cm}^{-3}$ ).

G4SSA-S (Fig. 3c) is larger in the Northern Hemisphere winter (Fig. S3). The warming over northern Europe and Asia in G4SSA relative to G4SSA-S is the characteristic "winter warming" from volcanic stratospheric aerosols (Robock, 2000). However, the zonal mean stratospheric temperatures in G4SSA and G4SSA-S differ substantially (Fig. 4). Sulfate aerosols in the stratosphere result in strong warming by $3 \mathrm{~K}$ in the tropics (Fig. 4a), while in G4SSA-S there is slight cooling (Fig. 4b), consistent with previous studies (Tilmes et al., 2009; Ammann et al., 2010; Jones et al., 2011). The slight warming in the lower stratosphere under G4SSA-S (Fig. 4b) might be a result of ozone changes and dynamical heating (discussion in Sect. 3.3.2). In both cases, the troposphere shows strong temperature reduction with similar patterns and ranges.

Global averaged precipitation and evaporation have similar reductions of $0.07 \mathrm{~mm} \mathrm{day}^{-1}$ in the two scenarios (Figs. 2b and S4), with no statistically significant difference between them. Most of the evaporation terms show a larger reduction in G4SSA than in G4SSA-S, except for plant transpiration, which has the opposite pattern (Fig. S4). As shown by Xia et al. (2016), enhanced diffuse radiation in G4SSA increases photosynthesis, which produces stronger transpiration. Therefore, transpiration in G4SSA reduces less than in G4SSA-S.

The similar evaporation reduction in G4SSA and G4SSA$S$ can also be explained by the surface energy budget (Fig. 5b). Although we keep the net shortwave radiation at the TOA the same in the two schemes (Figs. 1a and 5a), surface net solar radiation reduces more in G4SSA than in G4SSA-S (Figs. 2c and 5b) due to the absorption by sulfate aerosols in the near-infrared. This stronger surface solar forcing in G4SSA-S is mainly balanced by larger net longwave radiation to the atmosphere (Fig. 5). As a result, latent heat changes in the two scenarios are similar.
Here, precipitation and evaporation changes are very similar under sulfate and solar geoengineering. This is different from previous studies by Niemeier et al. (2013) and Ferraro et al. (2014), who found that the effect on the hydrological cycle is larger for sulfate geoengineering. These differences are related to the experimental design. Niemeier et al. (2013) bias-corrected all geoengineering scenarios to keep the net total flux at the TOA the same as that in 2020, while we keep the same net solar flux at the TOA in G4SSA and G4SSA-S (Fig. 1a). However, we found that the net total fluxes at the top of the model in G4SSA and G4SSA-S are similar as well (Figs. 5a and S5). Therefore, differences in the TOA boundary conditions might not be the main reason for the different hydrological cycle responses. In their studies, with the same magnitude of surface cooling, the sulfate injection scenario led to a greater reduction in globally averaged evaporation and precipitation as compared with the solar case. Ferraro et al. (2014) attributed the enhanced hydrological cycle response to sulfate geoengineering to extra downwelling longwave radiation because of stratospheric heating from the injected aerosols. Sulfate geoengineering thus led to a relative stabilization of the troposphere (by heating the upper troposphere more than the mid-lower troposphere) compared with the solar reduction case (which we do not find; Fig. 4c). A more stratified troposphere, in turn, results in a stronger reduction in latent heat fluxes and precipitation (similar to theoretical considerations by Bala et al., 2008). We find two possible reasons for the different response in our experiments. (1) The column ozone change could play an important role. In Niemeier et al. (2013) and Ferraro et al. (2014), the same prescribed ozone was used in all scenarios, while we used a fully coupled atmosphere-chemistry model. As shown in Sect. 3.2, total column ozone in G4SSA reduces by about 5 Dobson Units (DU) (mainly in the lower stratosphere) compared with RCP6.0 and G4SSA-S (Fig. 6). Less ozone in G4SSA will change its radiative forcing, surface radiative 
TOA/TOM

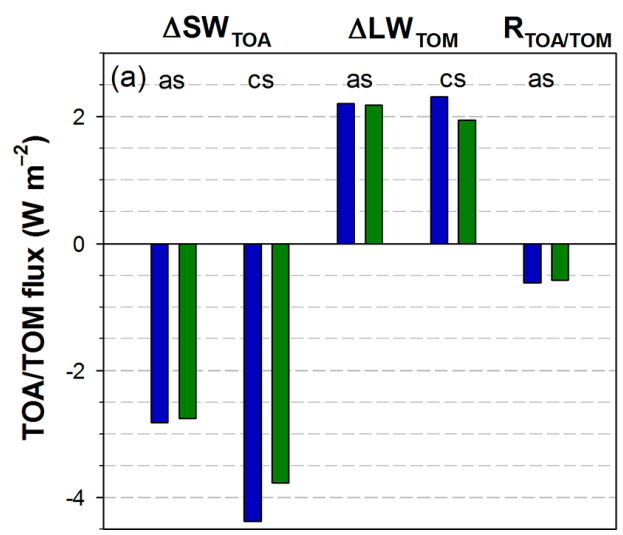

Surface

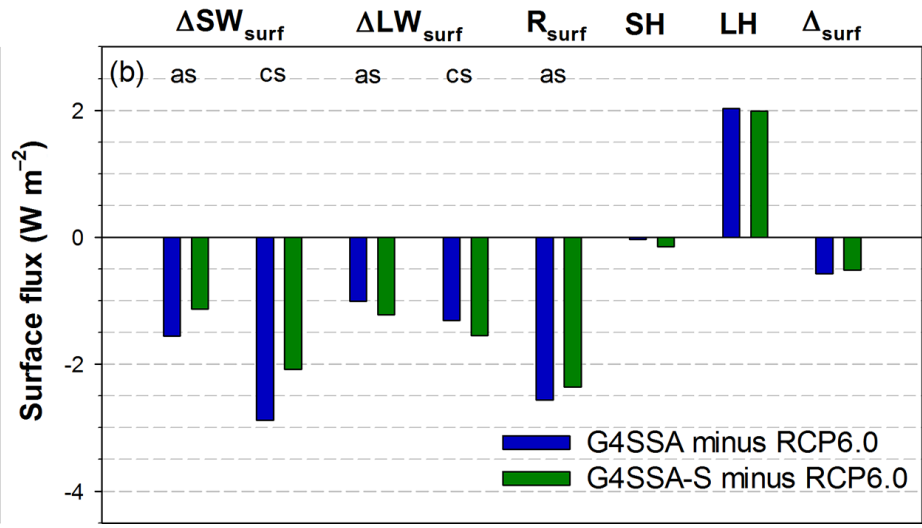

Figure 5. Energy flux (a) the top of the atmosphere (TOA)/the top of the model (TOM) (b) and at the surface (surf), shown as G4SSA minus RCP6.0 and G4SSA-S minus RCP6.0 for 2030-2069. For all fluxes, downwelling is positive. $\Delta$ SW is the net shortwave flux, $\Delta$ LW is the net longwave flux, $\mathrm{R}$ is the sum of $\Delta \mathrm{SW}$ and $\Delta \mathrm{LW}, \mathrm{SH}$ is sensible heat, $\mathrm{LH}$ is latent heat, and $\Delta_{\text {surf }}$ is the sum of $\Delta \mathrm{SW}_{\text {surf }}, \Delta \mathrm{LW}$ surf, $\mathrm{SH}$, and $\mathrm{LH}$; as is all sky and cs is clear sky.
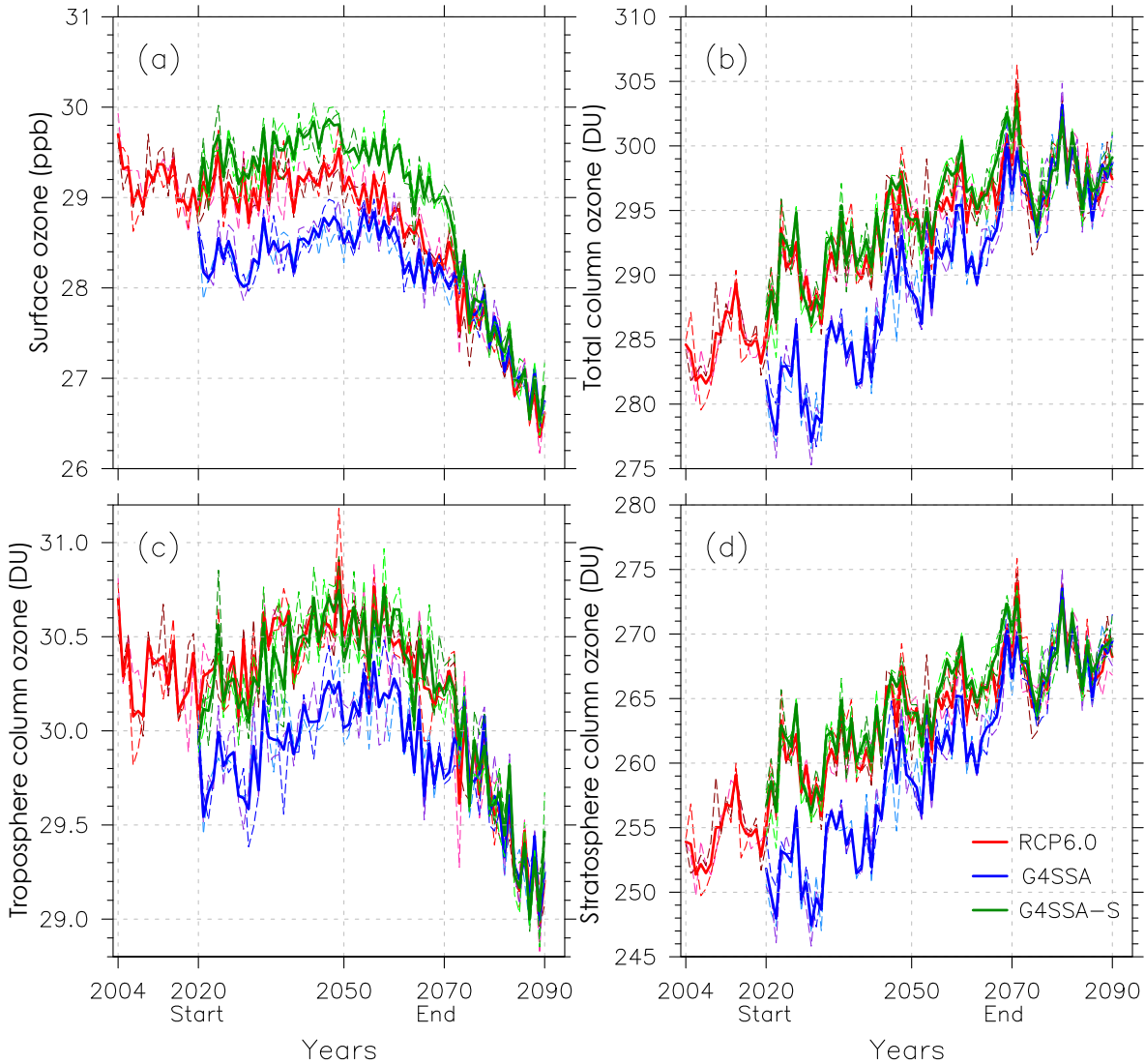

Figure 6. (a) Global averaged annual surface ozone concentrations (ppb), (b) total column ozone (DU), (c) tropospheric column ozone (DU), and (d) stratospheric column ozone (DU). An ozone concentration of $150 \mathrm{ppb}$ is used as the boundary of tropospheric ozone and stratospheric ozone. Dashed lines are ensemble members, and solid lines are the average of the three ensemble members. Geoengineering starts on 1 January 2020 and ends on 1 January 2070. 
fluxes and atmospheric lapse rate (Chiodo and Polvani, 2015; MacIntosh et al., 2016; Nowack et al., 2015, 2017) and thus contribute to the differences between the two studies. (2) Enhanced transpiration in G4SSA due to enhanced diffuse radiation reduces the evaporation difference in the two SRM schemes as discussed above.

\subsection{Surface and tropospheric ozone response}

The ozone response is remarkably different in G4SSA and G4SSA-S. Global mean surface ozone increases under G4SSA-S and decreases under G4SSA, relative to RCP6.0 (Fig. 6a). The total ozone column is dominated by stratospheric column ozone and shows strong reduction under G4SSA compared to RCP6.0, while the increase under G4SSA-S is small (Fig. 6b and d). The underlying upward trends of total column ozone as well as stratospheric ozone in all three scenarios are in line with the gradually declining stratospheric halogen content over time (Fig. $6 \mathrm{~b}$ and d). The halogen loading in the three scenarios is the same, and more information can be found in Morgenstern et al. (2017). As there is less halogen in the stratosphere toward the end of the geoengineering, stratospheric ozone is recovering (Fig. 6d) and there is less reduction in the total ozone column in G4SSA relative to RCP6.0 (Fig. 6b). The agreement across the simulations concerning interannual and decadal variations is because of the imposed QBO and 11-year solar cycles in all the runs. The decreasing tropospheric ozone column and surface ozone after the year 2060 in all scenarios results from decreases in global ozone precursor emissions following the RCP6.0 scenario (Young et al., 2013).

The surface ozone concentration distributions in the three scenarios are similar, with the highest concentration over the continents in the Northern Hemisphere (NH) (Fig. S6), while the concentration differences as well as the percentage difference between scenarios are spatially variable (Figs. 7 and S7). This highlights that the key driver behind the absolute surface ozone abundances is the underlying ozone precursor emissions following the RCP6.0 scenario. SRM is only a modulating factor, but depending on the SRM scheme even the sign of its impact can differ; global mean surface ozone concentrations in G4SSA are lower, relative to RCP6.0, whereas there are moderate surface ozone increases over the tropics (Fig. 7a). The strongest surface ozone reductions compared with RCP6.0 occur in NH midlatitudes across all seasons (Fig. S8a-d) and Southern Hemisphere (SH) mid- to high latitudes in MAM and JJA (Fig. S8b, c). In G4SSA-S, surface ozone also increases in the tropics relative to RCP6.0 (Fig. 7b), and this regional change is greater than in G4SSA (Fig. 7c). Surface ozone decreases, however, are found at $\mathrm{NH}$ midlatitudes over the continents during all seasons (Fig. S8e-h). Comparing the two types of geoengineering experiments directly, surface ozone concentrations are generally lower in G4SSA than in G4SSA-S (Fig. 7c), with peak differences in terms of absolute changes $(\mathrm{ppb})$ at
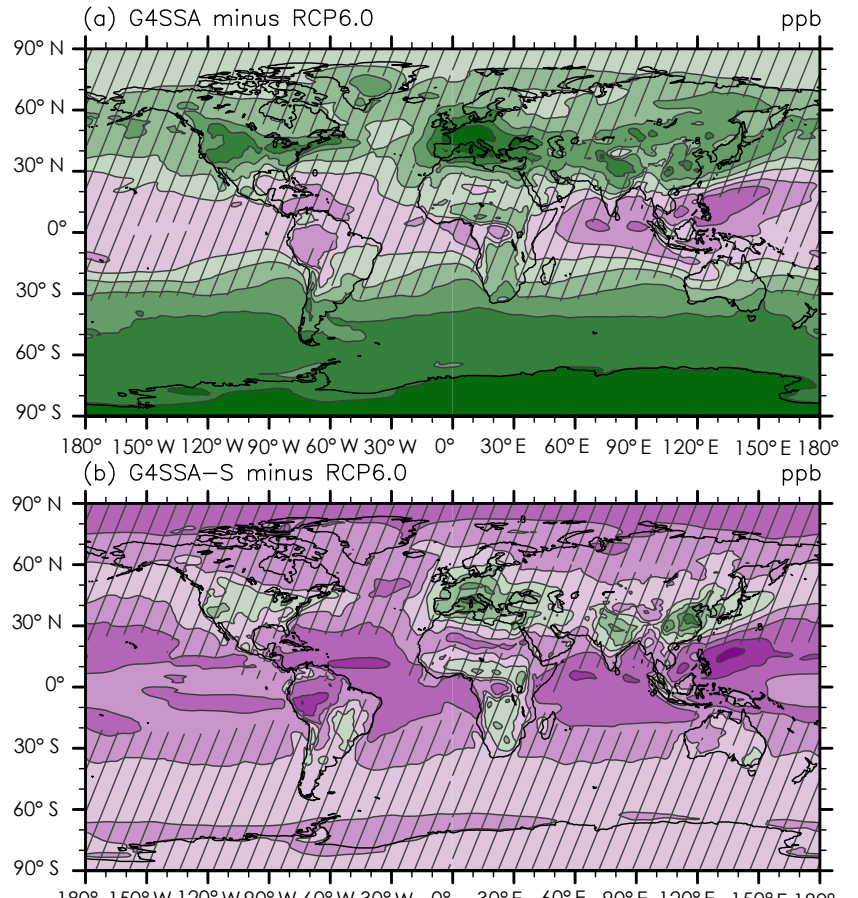

$180^{\circ} 150^{\circ} \mathrm{W} 120^{\circ} \mathrm{W} 90^{\circ} \mathrm{W} 60^{\circ} \mathrm{W} 30^{\circ} \mathrm{W} \quad 0^{\circ} \quad 30^{\circ} \mathrm{E} \quad 60^{\circ} \mathrm{E} \quad 90^{\circ} \mathrm{E} \quad 120^{\circ} \mathrm{E} \quad 150^{\circ} \mathrm{E} 180^{\circ}$
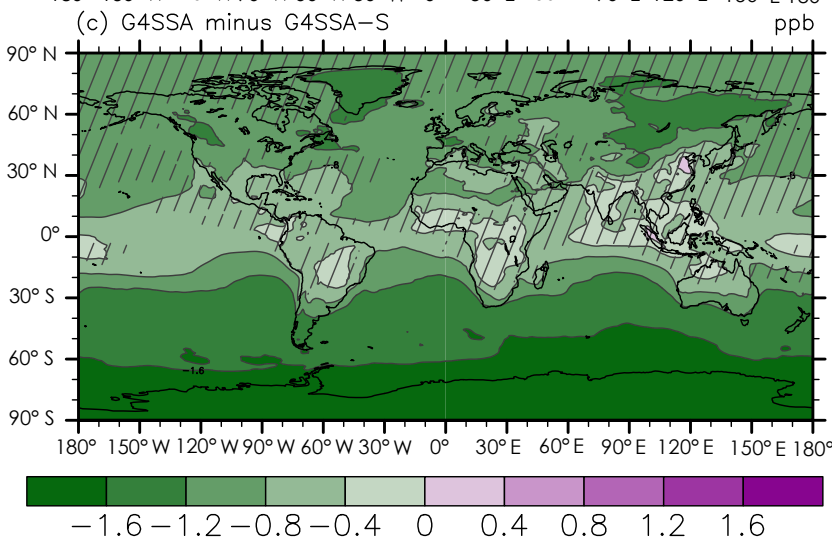

Figure 7. Global maps of surface ozone concentration differences (ppb) between (a) G4SSA and RCP6.0, (b) G4SSA-S and RCP6.0, and (c) G4SSA and G4SSA-S for 2030-2069. Hatched regions are insignificant, with $p>0.05$.

SH mid- to high latitudes in MAM and JJA (Fig. S8i and j) and at NH mid- to high latitudes in DJF (Fig. S81).

\subsection{Mechanisms of surface ozone change}

Surface ozone concentrations are determined by chemical production and loss controlled by emissions of ozone precursors and the composition of the atmosphere, loss due to surface deposition of ozone, and the transport of ozone from other regions of the atmosphere (Monks et al., 2015). Since all scenarios considered here are based on the same RCP6.0 emission scenario of ozone precursors, such as nitrogen oxide $\left(\mathrm{NO}_{\mathrm{x}}\right)$ and methane $\left(\mathrm{CH}_{4}\right)$, the differences in surface ozone must necessarily be driven by changes in cli- 
Table 1. Tropospheric ozone production and loss rates $\left(\mathrm{Tg} \mathrm{yr}^{-1}\right)$ over the period of the years 2030-2069 (average of three ensemble members). For chemical ozone production and ozone loss the net impacts of only the most important reaction pathways are listed.

\begin{tabular}{|c|c|c|c|}
\hline & RCP6.0 & G4SSA & G4SSA-S \\
\hline $\mathrm{O}_{3}$ net chemical change & 346.1 & 472.7 & 384.8 \\
\hline $\mathrm{O}_{3}$ tropospheric dry deposition & 901.5 & 891.5 & 909.4 \\
\hline $\mathrm{O}_{3} \mathrm{STE}^{*}$ & 555.4 & 418.8 & 524.6 \\
\hline $\mathrm{O}_{3}$ production & 4895.8 & 4764.0 & 4671.8 \\
\hline$r-\mathrm{NO}-\mathrm{HO}_{2}$ & 3087.3 & 3031.0 & 2964.8 \\
\hline$r-\mathrm{CH}_{3} \mathrm{O}_{2}-\mathrm{NO}$ & 1132.3 & 1105.2 & 1083.1 \\
\hline$r-\mathrm{PO}_{2}-\mathrm{NO}$ & 21.8 & 20.1 & 19.9 \\
\hline$r-\mathrm{CH}_{3} \mathrm{CO}_{3}-\mathrm{NO}$ & 183.1 & 172.2 & 171.2 \\
\hline$r-\mathrm{C}_{2} \mathrm{H}_{5} \mathrm{O} 2-\mathrm{NO}$ & 6.6 & 6.7 & 6.7 \\
\hline $0.92 * r-\mathrm{ISOPO}_{2}-\mathrm{NO}$ & 149.8 & 135.3 & 134.0 \\
\hline$r-\mathrm{MACRO}_{2}-\mathrm{NOa}$ & 76.1 & 69.8 & 69.5 \\
\hline$r-\mathrm{MCO}_{3}-\mathrm{NO}$ & 34.5 & 30.5 & 30.3 \\
\hline$r-\mathrm{RO}_{2}-\mathrm{NO}$ & 12.2 & 11.5 & 11.5 \\
\hline$r-\mathrm{XO}_{2}-\mathrm{NO}$ & 66.5 & 60.8 & 60.5 \\
\hline $0.9^{*} r-\mathrm{TOLO}_{2}-\mathrm{NO}$ & 4.1 & 4.1 & 4.1 \\
\hline$r-\mathrm{TERPO}_{2}-\mathrm{NO}$ & 18.1 & 16.9 & 16.8 \\
\hline $0.9^{*} r-\mathrm{ALKO}_{2}-\mathrm{NO}$ & 22.9 & 23.0 & 22.9 \\
\hline$r-\mathrm{ENEO}_{2}-\mathrm{NO}$ & 12.5 & 11.6 & 11.7 \\
\hline$r-\mathrm{EO}_{2}-\mathrm{NO}$ & 36.8 & 34.6 & 34.5 \\
\hline$r-\mathrm{MEKO}_{2}-\mathrm{NO}$ & 17.7 & 17.9 & 17.8 \\
\hline $0.4^{*} r$-ONITR-OH & 7.5 & 6.8 & 6.8 \\
\hline$r$-jonitr & 1.4 & 1.2 & 1.2 \\
\hline $\mathrm{O}_{3}$ loss & 4421.1 & 4158.6 & 4151.6 \\
\hline$r-\mathrm{O}(1 \mathrm{D})-\mathrm{H}_{2} \mathrm{O}$ & 2430.4 & 2286.5 & 2263.5 \\
\hline$r-\mathrm{OH}-\mathrm{O}_{3}$ & 548.2 & 528.3 & 527.0 \\
\hline$r-\mathrm{HO}_{2}-\mathrm{O}_{3}$ & 1288.9 & 1216.7 & 1232.9 \\
\hline$r-\mathrm{C}_{3} \mathrm{H}_{6}-\mathrm{O}_{3}$ & 13.8 & 11.5 & 11.5 \\
\hline $0.9^{*} r-\mathrm{ISOP}_{3} \mathrm{O}_{3}$ & 71.4 & 58.0 & 57.6 \\
\hline$r-\mathrm{C}_{2} \mathrm{H}_{4}-\mathrm{O}_{3}$ & 9.3 & 7.8 & 8.0 \\
\hline $0.8^{*} r-\mathrm{MVK}^{-\mathrm{O}_{3}}$ & 18.6 & 15.5 & 15.7 \\
\hline $0.8^{*} r$-MACR-O ${ }_{3}$ & 3.5 & 2.9 & 2.9 \\
\hline$r-\mathrm{C}_{10} \mathrm{H}_{16}-\mathrm{O}_{3}$ & 37.0 & 31.5 & 31.6 \\
\hline
\end{tabular}

* $\mathrm{O}_{3}$ STE is ozone transported through the stratosphere-troposphere exchange. We calculated this value using the following equation:

$\mathrm{O}_{3 \mathrm{STE}}+\mathrm{O}_{3 \text { net tropospheric chemical change }}+\mathrm{O}_{3 \text { dry tropospheric deposition }}=0$.

Tropospheric ozone is defined by the $150 \mathrm{ppb}$ isopleth.

mate in response to the geoengineering interventions, which include changes in temperature, humidity, atmospheric dynamics, and the photochemical environment. To understand the differences mechanistically, it is helpful to consider the impact of geoengineering on the tropospheric ozone budget.

The upper part of Table 1 shows the sources (production and net transport from the stratosphere (STE)) and sinks (loss rates and dry deposition) of tropospheric ozone. Both G4SSA and G4SSA-S show a positive net chemical change in tropospheric ozone (chemical production minus loss) and negative change in the STE of ozone relative to RCP6.0. However, the magnitude of these changes is significantly different. Compared with RCP6.0, tropospheric ozone net chemical change increases by $\sim 125$ and $\sim 40 \mathrm{Tg} \mathrm{yr}^{-1}$ in G4SSA and G4SSA-S, respectively, whereas the STE of ozone decreases by $\sim 140 \mathrm{Tg} \mathrm{gr}^{-1}(\sim 25 \%)$ and $\sim 30 \mathrm{Tg} \mathrm{yr}^{-1}(\sim 5 \%)$ in G4SSA and G4SSA-S, respectively. The positive net chemical changes are the result of reductions in both chemical ozone production and loss under G4SSA and G4SSA-S relative to RCP6.0, with larger reductions in ozone loss reactions (Table 1). Specifically, G4SSA-S shows a $\sim 90 \mathrm{Tg} \mathrm{yr}^{-1}$ larger decrease in ozone chemical production, whereas ozone loss budgets are reduced by similar magnitudes for the two SRM schemes (262.5 and $269.5 \mathrm{Tg} \mathrm{yr}^{-1}$ ). Combining the chemical and transport changes, the tropospheric ozone budget decreases under G4SSA and increases under G4SSA-S relative to RCP6.0, which is consistent with the overall surface ozone changes.

The reasons for these specific changes are discussed in detail in the following two sections. Then, the impacts of the factors are combined to explain regional surface ozone differences, as shown in Fig. 7.

\subsubsection{Chemical ozone production and loss in the troposphere}

Changes in tropospheric water vapor concentrations and the tropospheric photolysis environment under G4SSA and G4SSA-S are key to understand the differences in tropospheric ozone production and loss. This result is consistent with the results of a previous study for the case of solar geoengineering under a more idealized forcing scenario (Nowack et al., 2016).

To explain this, we briefly reiterate that tropospheric ozone $\left(\mathrm{O}_{3}\right)$ production is driven by the photolysis of nitrogen dioxide $\left(\mathrm{NO}_{2}\right)$ and the subsequent formation of ozone via a three-body reaction with resulting ground-state atomic oxygen $\mathrm{O}\left({ }^{3} \mathrm{P}\right)$ (Monks, 2005):

$\mathrm{NO}_{2}+h v(\lambda<420 \mathrm{~nm}) \rightarrow \mathrm{NO}+\mathrm{O}\left({ }^{3} \mathrm{P}\right)$,

$\mathrm{O}\left({ }^{3} \mathrm{P}\right)+\mathrm{O}_{2}+M \rightarrow \mathrm{O}_{3}+M$,

where $M$ is an inert collision partner (mostly molecular nitrogen). $\mathrm{NO}_{2}$ formation in turn is crucially dependent on the oxidation of $\mathrm{NO}$ by reaction with peroxides present in the troposphere, for example,

$\mathrm{HO}_{2}+\mathrm{NO} \rightarrow \mathrm{NO}_{2}+\mathrm{OH}$

$\mathrm{RO}_{2}+\mathrm{NO} \rightarrow \mathrm{NO}_{2}+\mathrm{RO}$,

where $R$ represents general organic residues such as $\mathrm{CH}_{3}$ (row 6 in Table 1). $\mathrm{RO}_{2}$ in turn is produced by oxidation reactions between VOCs and the hydroxyl radical $\mathrm{OH}$. Tropospheric $\mathrm{OH}$ is formed primarily by ozone photolysis and the subsequent reaction of excited atomic oxygen $\mathrm{O}\left({ }^{1} \mathrm{D}\right)$ with water vapor:

$\mathrm{O}_{3}+h v(\lambda<320 \mathrm{~nm}) \rightarrow \mathrm{O}\left({ }^{1} \mathrm{D}\right)+\mathrm{O}_{2}$,

$\mathrm{O}\left({ }^{1} \mathrm{D}\right)+\mathrm{H}_{2} \mathrm{O} \rightarrow 2 \mathrm{OH}$.

Reaction (R6) competes with several other reactions due to the high reactivity of $\mathrm{O}\left({ }^{1} \mathrm{D}\right)$. However, most importantly, 
the majority of $\mathrm{O}\left({ }^{1} \mathrm{D}\right)$ is quenched by collision with inert molecules such as molecular nitrogen to ground-state atomic oxygen $\mathrm{O}\left({ }^{3} \mathrm{P}\right)$, which subsequently undergoes reformation to $\mathrm{O}_{3}$ via a three-body Reaction (R2). Therefore, tropospheric ozone production and loss are strongly linked to concentrations of water vapor and the photochemical environment (availability of UV) in the troposphere.

In the case of clean (low $\mathrm{NO}_{\mathrm{x}}$ ) environments, lower water vapor concentrations (mainly in the tropical region $30^{\circ} \mathrm{N}-$ $30^{\circ} \mathrm{S}$ ) (Fig. S9) lead to less ozone loss via Reactions (R5) and (R6) and additional reactions with the formed $\mathrm{HO}_{x}$ species $\left(r-\mathrm{O}(1 \mathrm{D})-\mathrm{H}_{2} \mathrm{O}, r-\mathrm{OH}-\mathrm{O}_{3}\right.$, and $r-\mathrm{HO}_{2}-\mathrm{O}_{3}$ in Table 1$)$. This happens at the expense of more quenching of $\mathrm{O}\left({ }^{1} \mathrm{D}\right)$ and subsequent recycling of ozone, thus resulting in ozone increases. In contrast, in polluted (high $\mathrm{NO}_{\mathrm{x}}$ ) environments, less $\mathrm{OH}$ formation under lower atmospheric water vapor concentrations leads to reduced formation of $\mathrm{RO}_{2}$ and $\mathrm{HO}_{2}$. Therefore, less $\mathrm{NO}_{2}$ is produced via Reactions (R3) and (R4), resulting in less catalytic ozone production via Reactions (R1) and (R2) $\left(r-\mathrm{NO}-\mathrm{HO}_{2}\right.$ and, e.g., $r-\mathrm{CH}_{3} \mathrm{O}_{2}-\mathrm{NO}$ in Table 1). Consequently, ozone production is reduced in $\mathrm{NO}_{\mathrm{x}}-$ polluted environments under lower atmospheric water vapor concentrations.

With these fundamentals in mind, it is possible to understand the sign of the tropospheric ozone loss and production rate changes summarized in Table 1. Under both G4SSA and G4SSA-S, the key objective is to achieve surface temperature decreases. Tropospheric water vapor concentrations (or specific humidity) are strongly coupled to surface temperatures because relative humidity does not change much with climate change (Soden and Held, 2006; Dessler and Sherwood, 2009), so that the surface cooling simultaneously reduces tropospheric specific humidity by $5-20 \%$ depending on region and altitude. As a result, less water vapor in both G4SSA and G4SSA-S reduces ozone chemical loss by $\sim 150 \mathrm{Tg} \mathrm{yr}^{-1}$ through Reactions (R5) and (R6). The resulting decrease in $\mathrm{HO}_{\mathrm{x}}$ leads to further reductions in ozone loss, i.e., via reaction with $\mathrm{OH}\left(\sim 20 \mathrm{Tg} \mathrm{yr}^{-1}\right)$ and $\mathrm{HO}_{2}(\sim 60-$ $70 \mathrm{Tg} \mathrm{yr}^{-1}$ ). Overall, these water vapor/ $/ \mathrm{HO}_{\mathrm{x}}$-related reactions explain $\sim 90 \%$ of the overall reduction in ozone loss under SRM compared to a future RCP6.0 simulation.

The reduction in atmospheric humidity also affects ozone production but to a smaller degree. Here, ozone production via reaction between $\mathrm{NO}$ and $\mathrm{HO}_{2}$ is the key factor in driving these changes, with reductions of $\sim 55$ and $120 \mathrm{Tg} \mathrm{yr}^{-1}$ for G4SSA and G4SSA-S, respectively. The signal of reduced $\mathrm{OH}$ production propagates through all other $\mathrm{NO}_{\mathrm{x}}$ catalyzed ozone production pathways involving $\mathrm{RO}_{2}$ via Reactions (R4) and subsequently (R1) and (R2). NO oxidation via the $\mathrm{CH}_{3} \mathrm{O}_{2}-\mathrm{NO}$ pathway decreases by $\sim 27$ and $49 \mathrm{Tg} \mathrm{yr}^{-1}$ in G4SSA and G4SSA-S. Changes in natural $\mathrm{NO}_{\mathrm{x}}$ emissions by lightning play a minor role in comparison. In both SRM schemes, the reduction in lightning-induced $\mathrm{NO}_{\mathrm{x}}$ is not significant in most regions, and there is no significant difference between the two SRM schemes (Fig. S10).
The changes in chemical ozone production rates tend to be smaller in the sulfate G4SSA experiment than in the case of a solar constant reduction in G4SSA-S. There are three possible factors that contribute to this:

1. The entire reaction cycle depends on the availability of sunlight to photolyze $\mathrm{O}_{3}$ and $\mathrm{NO}_{2}$. Since $\mathrm{SRM}$ schemes modulate the intensity of sunlight (here by $1 \%$ ) reaching the troposphere in order to mitigate tropospheric warming, this will necessarily also play a role in all changes to ozone production and loss reactions in our SRM simulations. More importantly, however, the sulfate injection geoengineering alters stratospheric ozone concentrations, which ultimately impacts the photochemical environment of the troposphere by changing radiative fluxes into the troposphere (DeMore et al., 1997; Nowack et al., 2016). For example, a reduced stratospheric column will help to stimulate the tropospheric photochemistry by allowing the more radiation-relevant Reactions (R1) and (R5) to propagate into the troposphere.

2. Diffuse radiation under G4SSA promotes the photosynthesis rate and increases canopy transpiration (Fig. S4). Therefore, we expect that water vapor concentration over the continents with plants would be slightly higher in G4SSA relative to G4SSA-S (Fig. S11). Those regions with higher water vapor (East Asia, South Asia, North America, South Africa) often overlap with regions of high $\mathrm{NO}_{\mathrm{x}}$ pollution (Fig. S12). $\mathrm{HO}_{\mathrm{x}}-\mathrm{NO}_{\mathrm{x}}$ coupling in these regions will thus contribute to the smaller reduction in ozone production in G4SSA than in G4SSA-S.

3. Different biogenic VOC emissions occur under G4SSA and G4SSA-S, which, due to their central role in forming $\mathrm{NO}_{2}$, are highly important for ozone production. In both scenarios, lower temperatures reduce the heat stress on the emitting plants and therefore reduce their VOC emissions (Tingey et al., 1980; Sharkey and Yeh, 2001; Lathière et al., 2005; Bornman et al., 2015) (e.g., bio-emitted isoprene; Fig. S13). However, at the same time enhanced diffuse radiation under G4SSA increases biogenic VOC emissions compared with G4SSA-S (Wilton et al., 2011) (Fig. S13i, j, k and 1). In Table 1, biogenic VOC-related ozone chemical production is generally very similar between G4SSA with G4SSA-S (e.g., $r$ - $\mathrm{ISOPO}_{2}-\mathrm{NO}, r-\mathrm{MACRO}_{2}-\mathrm{NOa}, r-\mathrm{MCO}_{3}-\mathrm{NO}$, and $r$-TERPO ${ }_{2}-\mathrm{NO}$ ) and contributes less than $2 \%$ to the overall difference between G4SSA and G4SSA-S.

\subsubsection{Changes in the stratosphere-troposphere exchange}

Stratospheric chemical and dynamical changes can impact tropospheric ozone not only by changing the tropospheric 


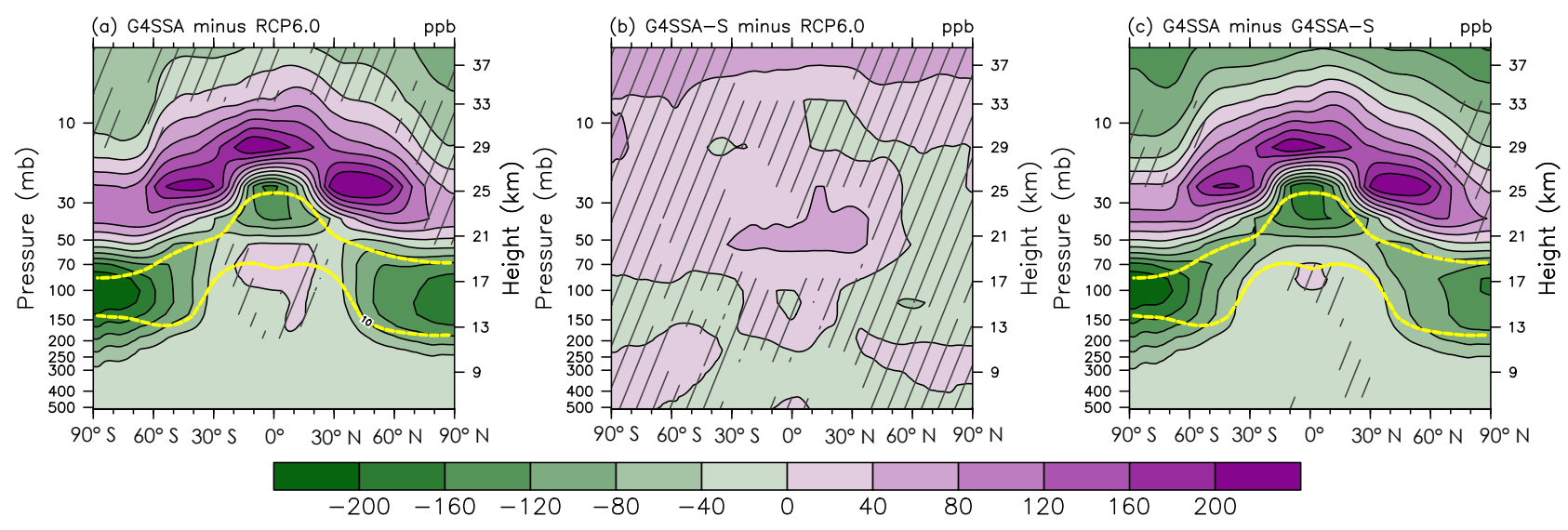

Figure 8. Zonal mean ozone concentration differences (ppb) in the geoengineering experiments, averaged for the three ensemble members for 2030-2069. Hatched regions are insignificant, with $p>0.05$. The yellow dashed lines in (a) and (c) are the upper and lower limits of the prescribed sulfate aerosol (surface area density: $10 \mu \mathrm{m}^{2} \mathrm{~cm}^{-3}$ ).

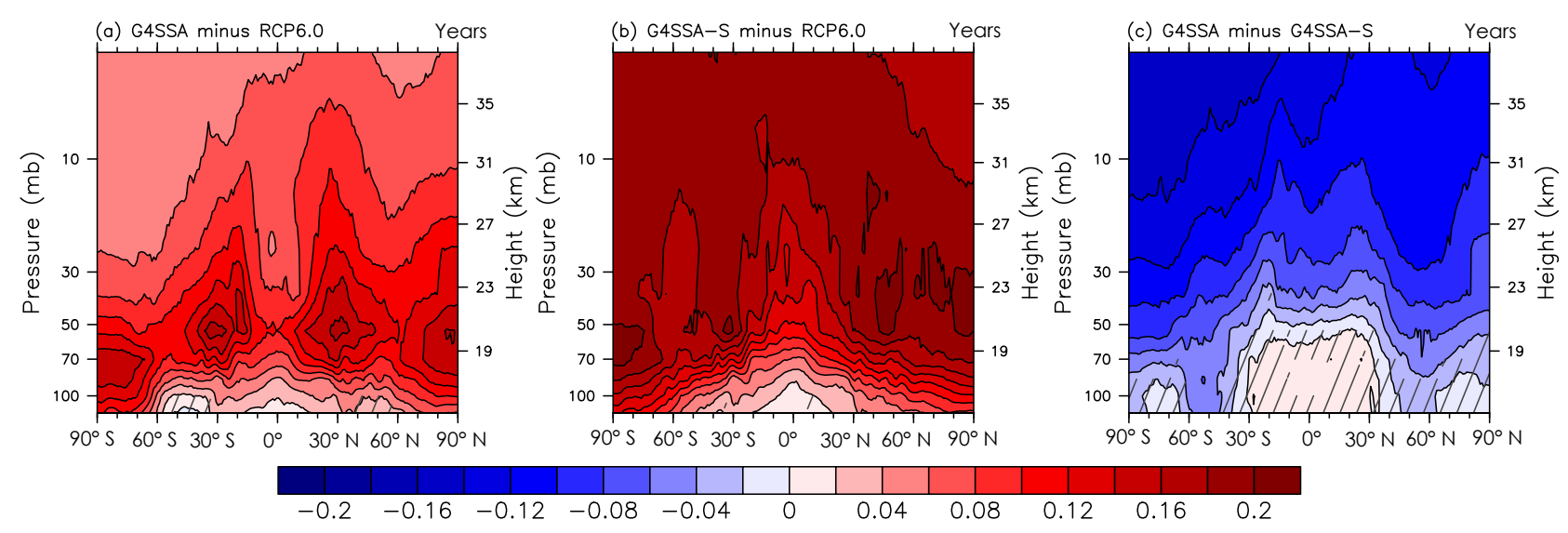

Figure 9. Zonal mean age of air differences (years) between (a) G4SSA and RCP6.0, (b) G4SSA-S and RCP6.0, and (c) G4SSA and G4SSA-S. They are averaged for the three ensemble members for 2030-2069. Hatched regions are insignificant, with $p>0.05$.

photochemical environment but also by changing the actual transport of ozone from the stratosphere into the troposphere (Hegglin and Shepherd, 2009; Neu et al., 2014). This can be either caused by changes in ozone concentrations in the stratosphere or by changes in the rate of the exchange of air masses between the stratosphere and the troposphere (i.e., the strength of the Brewer-Dobson (B-D) circulation and tropopause folds).

Figure 8 shows seasonal latitude-height cross sections of differences in ozone volume mixing ratios between G4SSA and RCP6.0 as well as G4SSA-S and RCP6.0 for altitudes above the $500 \mathrm{mb}$ pressure level. Under G4SSA, heterogeneous reactions on the aerosol surfaces lead to increased halogen activation and with that an enhancement of ozone depletion in mid- to high latitudes $\left(60-90^{\circ} \mathrm{N} / \mathrm{S}\right)$ in the lower stratosphere (70-150 mb) (Tilmes et al., 2008, 2009, 2012; Heckendorn et al., 2009). On the other hand, heterogenous reactions reduce the $\mathrm{NO}_{\mathrm{x}}$ to $\mathrm{NO}_{\mathrm{y}}$ ratio, which results in an increase in ozone mixing ratios, mainly in the middle strato- sphere (10-30 mb) (Tie and Brasseur, 1995) (Fig. 8a). In addition, changes in stratospheric temperature (warming in G4SSA and cooling in G4SSA-S) also change the photochemistry of ozone. Altogether, this results in year-round lower stratospheric ozone loss worldwide that peaks during the return of sunlight at high SH latitudes (Fig. S14). In comparison, the solar reduction in G4SSA-S does not enhance stratospheric heterogeneous reactions. The much smaller change (increase) in ozone (Fig. 8b) is driven by the change in homogeneous chemistry due to slight temperature reduction (Fig. 4b). However, in Fig. 4b, there is a slight warming around $50 \mathrm{mb}$ in the tropics, where ozone concentration also shows a stronger increase (Fig. 8b). As tropospheric cooling results in a slowdown of the B-D circulation (Fig. 9b) (Lin and Fu, 2013; Nowack et al., 2015; Shepherd and McLandress, 2011), there is an increase in ozone in the tropical upwelling region, which leads to increasing temperatures there as ozone is a strong shortwave and longwave absorber. The net result is small ozone increases in the tropical 


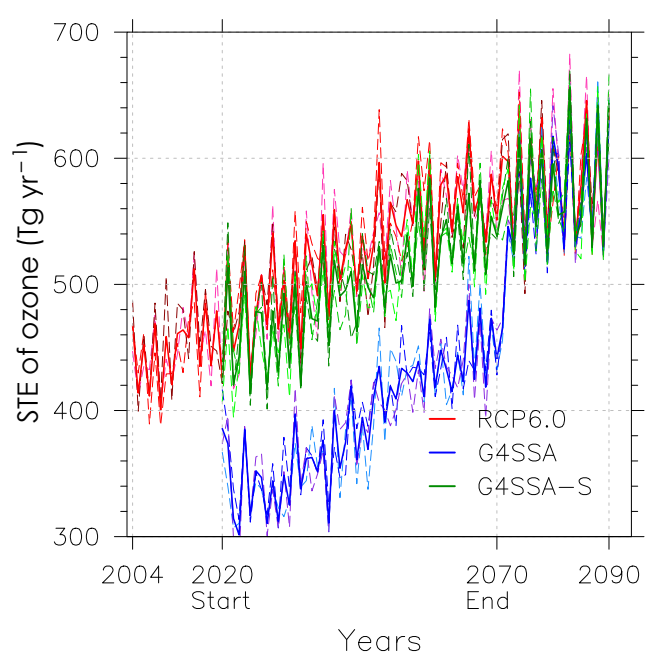

Figure 10. Global annual averaged ozone transported from the stratosphere to the troposphere (STE of ozone) in $\mathrm{Tg} \mathrm{yr}^{-1}$. Geoengineering starts on 1 January 2020 and ends on 1 January 2070.

lower stratosphere and decreases in both extratropical lower stratospheres (Fig. 8b).

The age of air is used to indicate the strength of the B-D circulation (Fig. 9). Here, it is calculated relative to the zonal mean of $1^{\circ} \mathrm{N}$ at $158.1 \mathrm{mb}$ (Garcia and Randel, 2008; Waugh, 2002). Older air indicates a slowdown of the B-D circulation. Compared with RCP6.0, both G4SSA and G4SSA-S show older air in the stratosphere indicating a slowdown of the circulation. The cooling effect in two SRM scenarios correlates with a weakening of tropical upwelling. However, in G4SSA, the heating of the tropical stratosphere results in enhanced lifting, which counteracts the weakening of the B-D circulation (Fig. 9a and c). Previous studies show controversial results on how the B-D circulation changes due to extra aerosols in the atmosphere. Aquila et al. (2012) modeled stronger tropic upwelling after the eruption of Mt Pinatubo, and other studies also found enhanced simulated B-D circulation after this volcano eruption (Aquila et al., 2013; Pitari et al., 2016). The differences between previous studies and our result may be because some previous studies used fixed ozone, with different stratospheric heating rates. In addition, in previous studies, the QBO was interactively simulated and the models had a higher model top. However, with extra black carbon in the stratosphere, the tropical upwelling weakens due to the simultaneous effect of tropospheric cooling (Shepherd and McLandress, 2011; Mills et al., 2014). We hope that future studies will address the potential model dependency of this result.

The sum of both effects, stratospheric chemical changes and the impact of B-D circulation change on the STE of ozone, is shown in Fig. 10. In G4SSA, ozone transported from the stratosphere to the troposphere is significantly decreased by $\sim 25 \%$ relative to RCP6.0. In G4SSA-S the reduction is small. Since the air mass transported from the stratosphere to the troposphere is reduced in both scenarios, and is even more strongly reduced under G4SSA-S (Fig. 9), we find that the enhanced stratospheric ozone depletion in G4SSA is the dominant reason for the strong reduction in the STE of ozone. This is also supported by a stratospheric ozone tracer from the model, $\mathrm{O}_{3}^{\text {Strat }}$, which is set to ozone mixing ratios in the stratosphere and experiences only chemical loss in the troposphere without chemical production (Fig. S15). We thus conclude that the significant changes in the STE of ozone in G4SSA are mainly driven by enhanced stratospheric ozone depletion catalyzed through the aerosols (see also Table 1).

\subsection{Balance of the different mechanisms and uncertainties}

In summary, there are two main factors that determine the tropospheric ozone responses in our SRM and RCP6.0 simulations: (a) changes in tropospheric ozone chemical production/loss due to water vapor changes and impacts on the photochemical environment of the troposphere as a result of both changes in stratospheric ozone and (to a smaller degree) the actual dimming of sunlight depending on the geoengineering scheme and (b) changes in the stratosphere-troposphere exchange of ozone.

These factors can also be used to explain the big picture behind the surface ozone changes shown in Fig. 7 . In G4SSA-S the reduced tropospheric humidity leads to stronger reductions in ozone loss than the decreases in ozone production, leading to global increases in surface ozone but particularly in clean-air oceanic environments in the tropics. This net increase in ozone chemical change is not canceled out by the slight reduction in ozone transport from the stratosphere (Fig. 10). In G4SSA, the reduction in ozone transport from the stratosphere is the controlling factor, which overwhelms the increase in net ozone production. The effect is particularly pronounced at mid- to high latitudes (Fig. S14a), thus giving rise to surface ozone decreases there (Fig. 7). In contrast, the effect of reduced tropospheric humidity is relatively more important in the tropics than in other regions, which results in a local increase in surface ozone under G4SSA. Regionally, $\mathrm{HO}_{\mathrm{x}}-\mathrm{NO}_{\mathrm{x}}$-induced reductions in ozone production (Table 1) can become important to explain surface ozone decreases in $\mathrm{NO}_{\mathrm{x}}$-polluted land areas in the $\mathrm{NH}$ for both scenarios (Figs. 7 and S6). Further minor contributions to the differences in surface ozone between G4SSA and G4SSA-S are a consequence of changes in water vapor due to regional canopy transpiration effects and biogenic VOC emissions (e.g., isoprene; Table 1 and Fig. S13).

This study may be biased by the following factors. (1) Using prescribed stratospheric aerosols does not allow the simulation of the full interactions between chemistry, aerosol microphysics, and dynamics. A fully interactive model including those interactions would be important. (2) The vertical resolution is not sufficient to produce an interactive 
QBO in the model used, which may also affect transport processes. (3) The model does not include the scattering effect of aerosols on tropospheric photolysis rates, which might lead to an overestimate of the UV enhancement in the troposphere.

\section{Conclusions}

Tropospheric ozone changes are to be expected in a geoengineered climate with consequent impacts on air pollution and crop yields. However, for the scenarios considered here, solar and sulfate geoengineering could have entirely different impacts, even in terms of the sign of the response, a rare discrepancy for a surface signal between these two types of geoengineering. There have been many studies using solar irradiance reductions to illustrate SRM. However, it turns out that different SRM strategies would have different impacts on hydrology, atmospheric dynamics, the terrestrial carbon sink, and, as investigated in this paper, tropospheric chemistry. These results also depend on the scenario of future ozone precursor and halogen emissions.

We have identified and explained the mechanisms by which stratospheric sulfate geoengineering would change surface ozone concentrations. We find that geoengineering might have the potential to significantly reduce some climate impacts, but it cannot fix the problem of air pollution. To reduce air pollution effectively, changes in surface emissions are key, with changes in climate (including geoengineering) being only a modulating factor (Monks et al., 2015; Stevenson et al., 2013; Young et al., 2013). More importantly, the surface ozone reduction between 2030 and 2070 in G4SSA is primarily the result of the decreased STE of ozone following ozone depletion in the stratosphere. The rather mild pollution benefit under the RCP6.0 background would thus be bought at the expense of a delay in stratospheric ozone recovery, which would result in enhanced UV penetration to Earth's surface and with that serious impacts on human health (e.g., skin cancer) and the ecosystem. In the future, potential increases in stratospheric ozone as a result of geoengineering may result in an increase in surface ozone, causing more ozone pollution. However, further analysis on air pollutants other than ozone is needed.

As shown by Pitari et al. (2014), impacts on ozone from stratospheric geoengineering can be highly model dependent. Therefore, we consider the results here to be a Geoengineering Model Intercomparison Project (GeoMIP) test bed experiment and encourage others to compare our results to those from other climate models to evaluate the robustness of the results presented here.

Data availability. The monthly atmospheric output from RCP6.0, G4SSA, and G4SSA-S are available on the NCAR Earth System
Grid at https://www.earthsystemgrid.org/dataset/ucar.cgd.ccsm4. geoeng.ccmi.html with https://doi.org/10.5065/D6DZ071N.

\section{The Supplement related to this article is available online at https://doi.org/10.5194/acp-17-11913-2017- supplement.}

Competing interests. The authors declare that they have no conflict of interest.

Special issue statement. This article is part of the special issue "The Geoengineering Model Intercomparison Project (GeoMIP): Simulations of solar radiation reduction methods (ACP/GMD interjournal SI)". It is not associated with a conference.

Acknowledgements. This work is supported by US National Science Foundation (NSF) grants AGS-1157525, GEO-1240507, AGS-1430051, and AGS-1617844. Computer simulations were conducted on the National Center for Atmospheric Research (NCAR) Yellowstone supercomputer. NCAR is funded by NSF. The CESM project is supported by NSF and the Office of Science (BER) of the US Department of Energy. Peer Nowack is supported by the European Research Council through the ACCI project, project number 267760 and is now supported through an Imperial College Research Fellowship. We thank Doug Kinnison for helpful comments and Jean-Francois Lamarque, Daniel Marsh, Andrew Conley, Louisa K. Emmons, Rolando R. Garcia, Anne K. Smith, and Douglas E. Kinnison for the CAM4-Chem development.

Edited by: Lynn M. Russell

Reviewed by: Ulrike Niemeier and two anonymous referees

\section{References}

Ainsworth, E. A., Yendrek, C. R., Sitch, S., Collins, W. J., and Emberson, L. D.: The effects of tropospheric ozone on net primary productivity and implications for climate change, Ann. Rev. Plant Biol., 63, 637-661, https://doi.org/10.1146/annurevarplant-042110-103829, 2012.

Ammann, C. M., Washington, W. M., Meehl, G. A., Buja, L., and Teng, H.: Climate engineering through artificial enhancement of natural forcings: Magnitudes and implied consequences, J. Geophys. Res., 115, D22109, https://doi.org/10.1029/2009JD012878, 2010.

Aquila, V., Oman, L. D., Stolarski, R. S., Colarco, P. R., and Newman, P. A.: Dispersion of the volcanic sulfate cloud from a Mount Pinatubo-like eruption, J. Geophys. Res., 117, D06216, https://doi.org/10.1029/2011JD016968, 2012.

Aquila, V., Oman, L. D., Stolarski, R. S., Douglass, A. R., and Newman, P. A.: The response of ozone and nitrogen dioxide to the eruption of Mt. Pinatubo at southern and northern midlatitudes, J. Atmos. Sci., 70, 894-900, https://doi.org/10.1175/JAS-D-120143.1, 2013. 
Ashmore, M. R.: Assessing the future global impacts of ozone on vegetation, Plant, Cell Environ., 28, 949-964, https://doi.org/10.1111/j.1365-3040.2005.01341.x, 2005.

Bala, G., Duffy, P. B., and Taylor, K. E.: Impact of geoengineering schemes on the global hydrological cycle, PNAS, 105, 76647669, https://doi.org/10.1073/pnas.0711648105, 2008.

Bornman, J. F., Barnes, P. W., Robinson, S. A., Ballaré, C. L., Flint, S. D., and Caldwell, M. M.: Solar ultraviolet radiation and ozone depletion-driven climate change: effects on terrestrial ecosystems, Photochem. Photobiol. Sci., 14, 88-107, https://doi.org/10.1039/C4PP90034K, 2015.

Chiodo, G. and Polvani, L. M.: Reduction of climate sensitivity of solar forcing due to stratospheric ozone feedback, J. Clim., 29, 4651-4663, https://doi.org/10.1175/JCLI-D-15-0721.1, 2015.

Collins, W. J., Derwent, R. G., Garnier, B., Johnson, C. E., and Sanderson, M. G.: Effect of stratosphere-troposphere exchange on the future tropospheric ozone trend, J. Geophys. Res., 108, 8528, https://doi.org/10.1029/2002JD002617, 2003.

Cooper, O. R., Parrish, D. D., Ziemke, J., Balashov, N. V., Cupeiro, M., Galbally, I. E., Gilge, S., Horowitz, L., Jensen, N. R., Lamarque, J.-F., Naik, V., Oltmans, S. J., Schwab, J., Shindell, D. T., Thompson, A. M., Thouret, V., Wang, Y., and Zbinden, R. M.: Global distribution and trends of tropospheric ozone: An observation-based review, Elem. Sci. Anth., 2-29, https://doi.org/10.12952/journal.elementa.000029, 2014.

Crutzen, P.: Albedo enhancement by stratospheric sulfur injections: A contribution to resolve a policy dilemma?, Climatic Change, 77, 211-220, https://doi.org/10.1007/s10584-006-9101-y, 2006.

DeMore, W. B., Sander, S. P., Golden, D. M., Hampson, R. F., Kurylo, M. J., Howard, C. J., Ravishankara, A. R., Kolb, C. E., and Molina, M. J.: Chemical Kinetics and Photochemical Data for Use in Stratospheric Modeling, Evaluation No. 12, JPL Publication 97-4, Jet Propulsion Laboratory, Pasadena, https: //jpldataeval.jpl.nasa.gov, 1997.

Dessler, A. E. and Sherwood, S. C.: A matter of humidity, Science, 323, 1020-1021, https://doi.org/10.1126/science.1171264, 2009.

Emmons, L. K., Walters, S., Hess, P. G., Lamarque, J.-F., Pfister, G. G., Fillmore, D., Granier, C., Guenther, A., Kinnison, D., Laepple, T., Orlando, J., Tie, X., Tyndall, G., Wiedinmyer, C., Baughcum, S. L., and Kloster, S.: Description and evaluation of the Model for Ozone and Related chemical Tracers, version 4 (MOZART-4), Geosci. Model Dev., 3, 43-67, https://doi.org/10.5194/gmd-3-43-2010, 2010.

Fernandez, R. P., Kinnison, D. E., Lamarque, J. F., Tilmes, S., and Saiz-Lopes, A.: Impact of biogenic very short-lived bromine on the Antarctic ozone hole during the 21st century, Atmos. Chem. Phys., 17, 1673-1688, https://doi.org/10.5194/acp-171673-2017, 2017.

Ferraro, A. J., Highwood, E. J., and Andrew J Charlton-Perez, A. J.: Weakened tropical circulation and reduced precipitation in response to geoengineering, Env. Res. Lett., 9, 014001, https://doi.org/10.1088/1748-9326/9/1/014001, 2014.

Forster, P., Ramaswamy, V., Artaxo, P., Berntsen, T., Betts, R., Fahey, D. W., Haywood, J., Lean, J., Lowe, D. C., Myhre, G., Nganga, J., Prinn, R., Raga, G., Schulz, M., and Van Dorland, R.: Changes in Atmospheric Constituents and in Radiative Forcing in: Climate Change 2007: The Physical Science Basis, Contribution of Working Group I to the Fourth Assessment Report of the Intergovernmental Panel on Climate Change,
Cambridge University Press, Cambridge, UK and New York, NY, USA, https://www.ipcc.ch/pdf/assessment-report/ar4/wg1/ ar4-wg1-chapter2.pdf, 2007.

Garcia, R. R. and Randel, W. J.: Acceleration of the Brewer-Dobson Circulation due to increases in greenhouse gases, J. Atmos. Sci., 65, 2731-2739, https://doi.org/10.1175/2008JAS2712.1, 2008.

Govindasamy, B. and Calderia, K.: Geoengineering Earth's radiation balance to mitigate $\mathrm{CO}_{2}$-induced climate change, Geophys. Res. Lett., 27, 2141-2144, https://doi.org/10.1029/1999GL006086, 2000.

Guenther, A. B., Jiang, X., Heald, C. L., Sakulyanontvittaya, T., Duhl, T., Emmons, L. K., and Wang, X. : The Model of Emissions of Gases and Aerosols from Nature version 2.1 (MEGAN2.1): an extended and updated framework for modeling biogenic emissions. Geosci. Model Dev., 5, 1471-1492, https://doi.org/10.5194/gmd-5-1471-2012, 2012.

Hartmann, D. L., Klein Tank, A. M. G., Rusticucci, M., Alexander, L. V., Brönnimann, S., Charabi, Y., Dentener, F. J., Dlugokencky, E. J., Easterling, D. R., Kaplan, A., Soden, B. J., Thorne, P. W., Wild, M., and Zhai, P. M.: Observations: Atmosphere and surface, in: Climate Change 2013: The Physical Science Basis, Contribution to Working Group 1 to the Fifth Assessment Report of the Intergovernmental Panel on Climate Change, edited by: Stocker, T. F., Qin. D., Plattner, G.-K., Tignor, M., Allen, S. K., Boschung, J., Nauels, A., Xia, Y., Bex, Y., and Midgley, P. M., Cambridge University Press, Cambridge, UK and New York, NY, USA, http://www.ipcc.ch/report/ar5/wg1, 2013.

Heckendorn, P., Weisenstein, D., Fueglistaler, S., Luo, B. P., Rozanov, E., Schraner, M., Thomason, L. W., and Peter, T.: The impact of geoengineering aerosols on stratospheric temperature and ozone, Environ. Res. Lett., 4, 045108, https://doi.org/10.1088/1748-9326/4/4/045108, 2009.

Hegglin, M. I. and Shepherd, T. G.: Large climate-induced changes in ultraviolet index and stratosphere-to-troposphere ozone flux, Nat. Geosci., 2, 687-691, https://doi.org/10.1038/ngeo604, 2009.

Jones, A., Haywood, J., and Boucher, O.: A comparison of the climate impacts of geoengineering by stratospheric $\mathrm{SO}_{2}$ injection and by brightening the marine stratocumulus cloud, Atmos. Sci. Let., 12, 176-183, https://doi.org/10.1002/asl.291, 2011.

Kampa, M. and Castanas, E.: Human health effects of air pollution, Environ. Pollut., 151, 362-367, https://doi.org/10.1016/j.envpol.2007.06.012, 2008.

Kinnison, D. E., Brasseur, G. P., Walters, S., Garcia, R. R., Marsh, D. R., Sassi, F., Harvey, V. L., Randall, C. E., Emmons, L., Lamarque, J.-F., Hess, P., Orlando, J. J., Tie, X. X., Randel, W., Pan, L. L., Gettelman, A., Granier, C., Diehl, T., Niemeier, U., and Simmons, A. J.: Sensitivity of chemical tracers to meteorological parameters in the MOZART3 chemical transport model, J. Geophys. Res., 112, D20302, https://doi.org/10.1029/2006JD007879, 2007.

Lamarque, J.-F., Bond, T. C., Eyring, V., Granier, C., Heil, A., Klimont, Z., Lee, D., Liousse, C., Mieville, A., Owen, B., Schultz, M. G., Shindell, D., Smith, S. J., Stehfest, E., Van Aardenne, J., Cooper, O. R., Kainuma, M., Mahowald, N., Mc- Connell, J. R., Naik, V., Riahi, K., and van Vuuren, D. P.: Historical (1850-2000) gridded anthropogenic and biomass burning emissions of reactive gases and aerosols: methodol- 
ogy and application, Atmos. Chem. Phys., 10, 7017-7039, https://doi.org/10.5194/acp-10-7017-2010, 2010.

Lamarque, J.-F., Emmons, L. K., Hess, P. G., Kinnison, D. E., Tilmes, S., Vitt, F., Heald, C. L., Holland, E. A., Lauritzen, P. H., Neu, J., Orlando, J. J., Rasch, P. J., and Tyndall, G. K.: CAM-Chem: Description and evaluation of interactive atmospheric chemistry in the Community Earth System Model, Geosci. Model Dev., 5, 369-411, https://doi.org/10.5194/gmd-5369-2012, 2012.

Lathière, J., Hauglustaine, D. A., De Noblet-Ducoudré, N., Krinner, G., and Folberth, G. A.: Past and future changes in biogenic volatile organic compound emissions simulated with a global dynamic vegetation model, Geophys. Res. Lett., 32, L20818, https://doi.org/10.1029/2005GL024164, 2005.

Lin, P. and Fu, Q.: Changes in various branches of the Brewer-Dobson circulation from an ensemble of chemistry climate models, J. Geophys. Res.-Atmos., 118, 73-84, https://doi.org/10.1029/2012JD018813, 2013.

MacIntosh, C. R., Allan, R. P., Baker, L. H., Bellouin, N., Collins, W., Mousavi, Z., and Shine, K. P.: Contrasting fast precipitation responses to tropospheric and stratospheric ozone forcing, Geophys. Res. Lett., 43, 1263-1271, https://doi.org/10.1002/2015GL067231, 2016.

Mauzerall, D. L. and Wang, X. P.: Protecting agricultural crops from the effects of tropospheric ozone exposure: Reconciling science and standard setting in the United States, Europe, and Asia, Annu. Rev. Energ. Env., 26, 237-268, https://doi.org/10.1146/annurev.energy.26.1.237, 2001.

Meinshausen, M., Smith, S. J., Calvin, K., Daniel, J. S., Kainuma, M. L., T., Lamarque, J.-F., Matsumoto, K., Montzka, S. A., Raper, S. C. B., Riahi, K., Thomson, A., Velders, G. J. M., and van Vuuren, D. P. P.: The RCP greenhouse gas concentrations and their extension from 1765 to 2300, Climatic Change, 109, 213-241, https://doi.org/10.1007/s10584-011-0156-z, 2011.

Mills, M., Toon, O. B., Lee-Taylor, J., and Robock, A.: Multidecadal global cooling and unprecedented ozone loss following a regional nuclear conflict, Earth's Future, 2, 161-176, https://doi.org/10.1002/2013EF000205, 2014.

Monks, P. S.: Gas-phase radical chemistry in the troposphere, Chem. Soc. Rev., 34, 376-395, https://doi.org/10.1039/b307982c, 2005.

Monks, P. S., Archibald, A. T., Colette, A., Cooper, O., Coyle, M., Derwent, R., Fowler, D., Granier, C., Law, K. S., Mills, G. E., Stevenson, D. S., Tarasova, O., Thouret, V., Von Schneidemesser, E., Sommariva, R., Wild, O., and Williams, M. L.: Tropospheric ozone and its precursors from the urban to the global scale from air quality to short-lived climate forcer, Atmos. Chem. Phys., 15, 8889-8973, https://doi.org/10.5194/acp-15-8889-2015, 2015.

Morgenstern, O., Hegglin, M. I., Rozanov, E., O’Connor, F. M., Abraham, N. L., Akiyoshi, H., Archibald, A. T., Bekki, S., Butchart, N., Chipperfield, M. P., Deushi, M., Dhomse, S. S., Garcia, R. R., Hardiman, S. C., Horowitz, L. W., Jöckel, P., Josse, B., Kinnison, D., Lin, M., Mancini, E., Manyin, M. E., Marchand, M., Marécal, V., Michou, M., Oman, L. D., Pitari, G., Plummer, D. A., Revell, L. E., Saint-Martin, D., Schofield, R., Stenke, A., Stone, K., Sudo, K., Tanaka, T. Y., Tilmes, S., Yamashita, Y., Yoshida, K., and Zeng, G.: Review of the global models used within phase 1 of the Chemistry-Climate
Model Initiative (CCMI), Geosci. Model Dev., 10, 639-671, https://doi.org/10.5194/gmd-10-639-2017, 2017.

Neu, J. L., Flury, T., Manney, G. L., Santee, M. L., Livesey, N. J., and Worden, J.: Tropospheric ozone variations governed by changes in stratospheric circulation, Nat. Geosci., 7, 340-344, https://doi.org/10.1038/NGEO2138, 2014.

Niemeier, U., Schmidt, H., Alterskjær, K., and Kristjánsson, J. E.: Solar irradiance reduction via climate engineering: Impact of different techniques on the energy balance and the hydrological cycle, J. Geophys. Res.-Atmos., 118, 11905-11917, https://doi.org/10.1002/2013JD020445, 2013.

Nowack, P. J., Abraham, N. L., Maycock, A. C., Braesicke, P., Gregory, J. M., Joshi, M. M., Osprey, A., and Pyle, J. A.: A large ozone-circulation feedback and its implications for global warming assessments, Nature Climate Change, 5, 41-45, https://doi.org/10.1038/nclimate2451, 2015.

Nowack, P. J., Abraham, N. L., Braesicke, P., and Pyle, J. A.: Stratospheric ozone changes under solar geoengineering: implications for UV exposure and air quality, Atmos. Chem. Phys., 16, 41914203, https://doi.org/10.5194/acpd-15-31973-2015, 2016.

Nowack, P. J., Braesicke, P., Abraham, N. L., and Pyle, J. A.: On the role of ozone feedback in the ENSO amplitude response under global warming, Geophys. Res. Lett., 44, 3858-3866, https://doi.org/10.1002/2016GL072418, 2017.

Pitari, G., Aquila, V., Kravitz, B., Robock, A., Watanabe, S., Cionni, I., De Luca, N., Genova, G. I., Mancini, E., and Tilmes, S.: Stratospheric ozone response to sulfate geoengineering: Results from the Geoengineering Model Intercomparison Project (GeoMIP), J. Geophys. Res.-Atmos., 119, 2629-2653, https://doi.org/10.1002/2013JD020566, 2014.

Pitari, G., Cionni, I., Genova, G. D., Visioni, D., Gandolfi, I., and Mancini, E.: Impact of stratospheric volcanic aerosols on age-ofair and transport of long lived species, Atmosphere, 7, 149 pp., https://doi.org/10.3390/atmos7110149, 2016.

Portmann, R. W., Solomon, S., Garcia, R. R., Thomason, L. W., Poole, L. R., and McCormick, M. P.: Role of aerosol variations in anthropogenic ozone depletion in the polar regions, J. Geophys. Res., 101, 22991-23006, https://doi.org/10.1029/96JD02608, 1996.

Rasch, P. J., Crutzen, P. J., and Coleman, D. B.: Exploring the geoengineering of climate using stratospheric sulfate aerosols: The role of particle size, J. Geophys. Res., 35, L02809, https://doi.org/10.1029/2007GL032179, 2008a.

Rasch, P. J., Tilmes, S., Turco, R. P., Robock, A., Oman, L., Chen, C-C., Stenchikov, G. L., and Garcia, R. R.: An overview of geoengineering of climate using stratospheric sulphate aerosols, Phil. Trans. R. Soc. A, 366, 4007-4037, https://doi.org/10.1098/rsta.2008.0131, 2008b.

Richter, J. H., Tilmes, S., Mills, M. J., Kravitz, B., MacMartin, D. G., Vitt, F., and Lamarque, J.-F.: Stratospheric dynamical response and ozone feedbacks in the presence of $\mathrm{SO}_{2}$ injection, $\mathrm{J}$. Geophys. Res.-Atmos., in press, 2017.

Robock, A.: Volcanic eruption and climate, Rev. Geophys., 38, 191219, https://doi.org/10.1029/1998RG000054, 2000.

Sander, S. P., Abbatt, J., Barker, J. R., Burkholder, J. B., Friedl, R. R., Golden, D. M., Huie, R. E., Kolb, C. E., Kurylo, M. J., Moortgat, G. K., Orkin, V. L., and Wine, P. H.: Chemical Kinetics and Photochemical Data for Use in Atmospheric Studies Evaluation No. 17, JPL Publication 10-6, Jet Propul- 
sion Laboratory, Pasadena, https://jpldataeval.jpl.nasa.gov/pdf/ JPL10-6Final15June2011.pdf, 2011.

Sharkey, T. D. and Yeh, S. S.: Isoprene emission from plants. Ann. Rev. Plant Phys. Plant Mol. Biol., 52, 407-436, https://doi.org/10.1146/annurev.arplant.52.1.407, 2001.

Shepherd, T. G. and McLandress, C.: A Robust Mechanism for Strengthening of the Brewer-Dobson Circulation in Response to Climate Change: Critical-Layer Control of Subtropical Wave Breaking, J. Atmos. Sci., 68, 784-797, https://doi.org/10.1175/2010JAS3608.1, 2011.

Silva, R. A., West, J. J., Zhang, Y., Anenberg, S. C., Lamarque, J.F., Shindell, D. T., Collins, W. J., Dalsoren, S., Faluvegi, G., Folberth, G., Horowitz, L. W., Nagashima, T., Naik, V., Rumbold, S., Skeie, R., Sudo, K., Takemura, T., Bergmann, D., CameronSmith, P., Cionni, I., Doherty, R. M., Eyring, V., Josse, B., MacKenzie, I. A., Plummer, D., Righi, M., Stevenson, D. S., Strode, S., Szopa, S. and Zeng, G.: Global premature mortality due to anthropogenic outdoor air pollution and the contribution of past climate change, Environ. Res. Lett., 8, 34005, https://doi.org/10.1088/1748-9326/8/3/034005, 2013

Soden, B. and Held, I.: An Assessment of Climate Feedbacks in Coupled Ocean - Atmosphere Models, J. Clim., 19, 3354-3360, https://doi.org/10.1175/JCLI9028.1, 2006.

Solomon, S.: Stratospheric ozone depletion: A review of concepts and history, Rev. Geophys., 37, 275-316, https://doi.org/10.1029/1999RG900008, 1999.

Stevenson, D. S., Dentener, F. J., Schultz, M. G., Ellingsen, K., van Noije, T. P. C., Wild, O., Zeng, G., Amann, M., Atherton, C. S., Bell, N., Bergmann, D. J., Bey, I., Butler, T., Cofala, J., Collins, W. J., Derwent, R. G., Doherty, R. M., Drevet, J., Eskes, H. J., Fiore, A. M., Gauss, M., Hauglustaine, D. A., Horowitz, L. W., Isaksen, I. S. A., Krol, M. C., Lamarque, J.-F., Lawrence, M. G., Montanaro, V., Müller, J.-F., Pitari, G., Prather, M. J., Pyle, J. A., Rast, S., Rodriguez, J. M., Sanderson, M. G., Savage, N. H., Shindell, D. T., Strahan, S. E., Sudo, K., and Szopa, S.: Multimodel ensemble simulations of present-day and near-future tropospheric ozone, J. Geophys. Res., 111, D08301, https://doi.org/10.1029/2005JD006338, 2006.

Stevenson, D. S., Young, P. J., Naik, V., Lamarque, J. F., Shindell, D. T., Voulgarakis, A., Skeie, R. B., Dalsoren, S. B., Myhre, G., Berntsen, T. K., Folberth, G. A., Rumbold, S. T., Collins, W. J., MacKenzie, I. A., Doherty, R. M., Zeng, G., Van Noije, T. P. C., Strunk, a., Bergmann, D., Cameron-Smith, P., Plummer, D. A., Strode, S. A., Horowitz, L., Lee, Y. H., Szopa, S., Sudo, K., Nagashima, T., Josse, B., Cionni, I., Righi, M., Eyring, V., Conley, A., Bowman, K. W., Wild, O., and Archibald, A.: Tropospheric ozone changes, radiative forcing and attribution to emissions in the Atmospheric Chemistry and Climate Model Intercomparison Project (ACCMIP), Atmos. Chem. Phys., 13, 3063-3085, https://doi.org/10.5194/acp-13-3063-2013, 2013.

Tang, Q., Hess, P. G., Brown-steiner, B., and Kinnison, D. E.: Tropospheric ozone decrease due to the Mount Pinatubo eruption?: Reduced stratospheric influx, Geophys. Res. Lett., 40, 55535558, https://doi.org/10.1002/2013GL056563, 2013.

Tie, X. and Brasseur, G.: The response of stratospheric ozone to volcanic eruptions: Sensitivity to atmospheric chlorine loading, Geophys. Res. Lett., 22, 3035-3038, https://doi.org/10.1029/95GL03057, 1995.
Tilmes, S., Müller, R., and Salawitch, R.: The sensitivity of polar ozone depletion to proposed geoengineering schemes, Science, 320, 1201-1204, https://doi.org/10.1126/science.1153966, 2008.

Tilmes, S., Garcia, R. R., Kinnison, D. E., Gettelman, A., and Rasch, P. J.: Impact of geoengineered aerosols on the troposphere and stratosphere, J. Geophys. Res., 114, D12305, https://doi.org/10.1029/2008JD011420, 2009.

Tilmes, S., Kinnison, D. E., Garcia, R. R., Salawitch, R., Canty, T., Lee-Taylor, J., Madronich, S., and Chance, K.: Impact of very short-lived halogens on stratospheric ozone abundance and UV radiation in a geo-engineered atmosphere, Atmos. Chem. Phys., 12, 10945-10955, https://doi.org/10.5194/acp-12-109452012, 2012.

Tilmes, S., Mills, M. J., Niemeier, U., Schmidt, H., Robock, A., Kravitz, B., Lamarque, J.-F., Pitari, G., and English, J. M.: A new Geoengineering Model Intercomparison Project (GeoMIP) experiment designed for climate and chemistry models, Geosci. Model Dev., 8, 43-49, https://doi.org/10.5194/gmd-8-43-2015, 2015.

Tilmes, S., Sanderson, B. M., and O’Neill, B. C.: Climate impacts of geoengineering in a delayed mitigation scenario, Geophys. Res. Lett., 43, 8222-8229, https://doi.org/10.1002/2016GL070122, 2016a.

Tilmes, S., Lamarque, J.-F., Emmons, L. K., Kinnison, D. E., Marsh, D., Garcia, R. R., Smith, A. K., Neely, R. R., Conley, A., Vitt, F., Val Martin, M., Tanimoto, H., Simpson, I., Blake, D. R., and Blake, N.: Representation of the Community Earth System Model (CESM1) CAM4-chem within the ChemistryClimate Model Initiative (CCMI), Geosci. Model Dev., 9, 18531890, https://doi.org/10.5194/gmd-9-1853-2016, 2016b.

Tingey, D. T., Manning, M., Grothaus, L. C., and Burns, W. F.: Influence of light and temperature on monoterpene emission rates from Slash Pine, Plant Physiol. 65, 797-801, https://doi.org/10.1104/pp.65.5.797, 1980.

Vingarzan, R.: A review of surface ozone background levels and trends, Atmos. Env., 38, 3431-3442, https://doi.org/10.1016/j.atmosenv.2004.03.030, 2004.

Waugh, D.: Age of stratospheric air: Theory, observations, and models, Rev. Geophys., 40, 1-26, https://doi.org/10.1029/2000RG000101, 2002.

Wigley, T. M. L.: A combined mitigation/geoengineering approach to climate stabilization, Science, 314, 452-454, https://doi.org/10.1126/science.1131728, 2006.

Wild, O.: Modelling the global tropospheric ozone budget: exploring the variability in current models, Atmos. Chem. Phys., 7, 2643-2660, https://doi.org/10.5194/acp-7-2643-2007, 2007.

Wild, O., Fiore, A. M., Shindell, D. T., Doherty, R. M., Collins, W. J., Dentener, F. J., Schultz, M. G., Gong, S., MacKenzie, I. A., Zeng, G., Hess, P., Duncan, B. N., Bergmann, D. J., Szopa, S., Jonson, J. E., Keating, T. J., and Zuber, A.: Modelling future changes in surface ozone: a parameterized approach, Atmos. Chem. Phys., 12, 2037-2054, https://doi.org/10.5194/acp12-2037-2012, 2012.

Wilton, D. J., Hewitt, C. N., and Beerling, D. J.: Simulating effect of changes in direct and diffuse radiation on canopy scale isoprene emissions from vegetation following volcanic eruptions, Atmos. Chem. Phys., 11, 11723-11731, https://doi.org/10.5194/acp-1111723-2011, 2011. 
Xia, L., Robock, A., Tilmes, S., and Neely III, R. R.: Stratospheric sulfate geoengineering could enhance the terrestrial photosynthesis rate, Atmos. Chem. Phys., 16, 1479-1489, https://doi.org/10.5194/acp-16-1479-2016, 2016.

Young, P. J., Archibald, A. T., Bowman, K. W., Lamarque, J.-F., Naik, V., Stevenson, D. S., Tilmes, S., Voulgarakis, A., Wild, O., Bergmann, D., Cameron-Smith, P., Cionni, I., Collins, W. J., Dalsøren, S. B., Doherty, R. M., Eyring, V., Faluvegi, G., Horowitz, L. W., Josse, B., Lee, Y. H., MacKenzie, I. A., Nagashima, T., Plummer, D. A., Righi, M., Rumbold, S. T., Skeie, R. B., Shindell, D. T., Strode, S. A., Sudo, K., Szopa, S., and Zeng, G.: Preindustrial to end 21 st century projections of tropospheric ozone from the Atmospheric Chemistry and Climate Model Intercomparison Project (ACCMIP), Atmos. Chem. Phys., 13, 20632090, https://doi.org/10.5194/acp-13-2063-2013, 2013. 